\title{
41BX68: A Preshitoric Quarry-Workshop In Northern Bexar County, Texas
}

\author{
A. Joachim McGraw \\ Fred Valdez Jr. \\ Department of Anthropology, The University of Texas at Austin
}

Follow this and additional works at: https://scholarworks.sfasu.edu/ita

Part of the American Material Culture Commons, Archaeological Anthropology Commons, Environmental Studies Commons, Other American Studies Commons, Other Arts and Humanities Commons, Other History of Art, Architecture, and Archaeology Commons, and the United States History Commons

Tell us how this article helped you.

This Article is brought to you for free and open access by the Center for Regional Heritage Research at SFA ScholarWorks. It has been accepted for inclusion in Index of Texas Archaeology: Open Access Gray Literature from the Lone Star State by an authorized editor of SFA ScholarWorks. For more information, please contact cdsscholarworks@sfasu.edu. 


\section{BX68: A Preshitoric Quarry-Workshop In Northern Bexar County, Texas \\ Creative Commons License \\ (c) (1) \& 8}

This work is licensed under a Creative Commons Attribution-NonCommercial 4.0 International License 


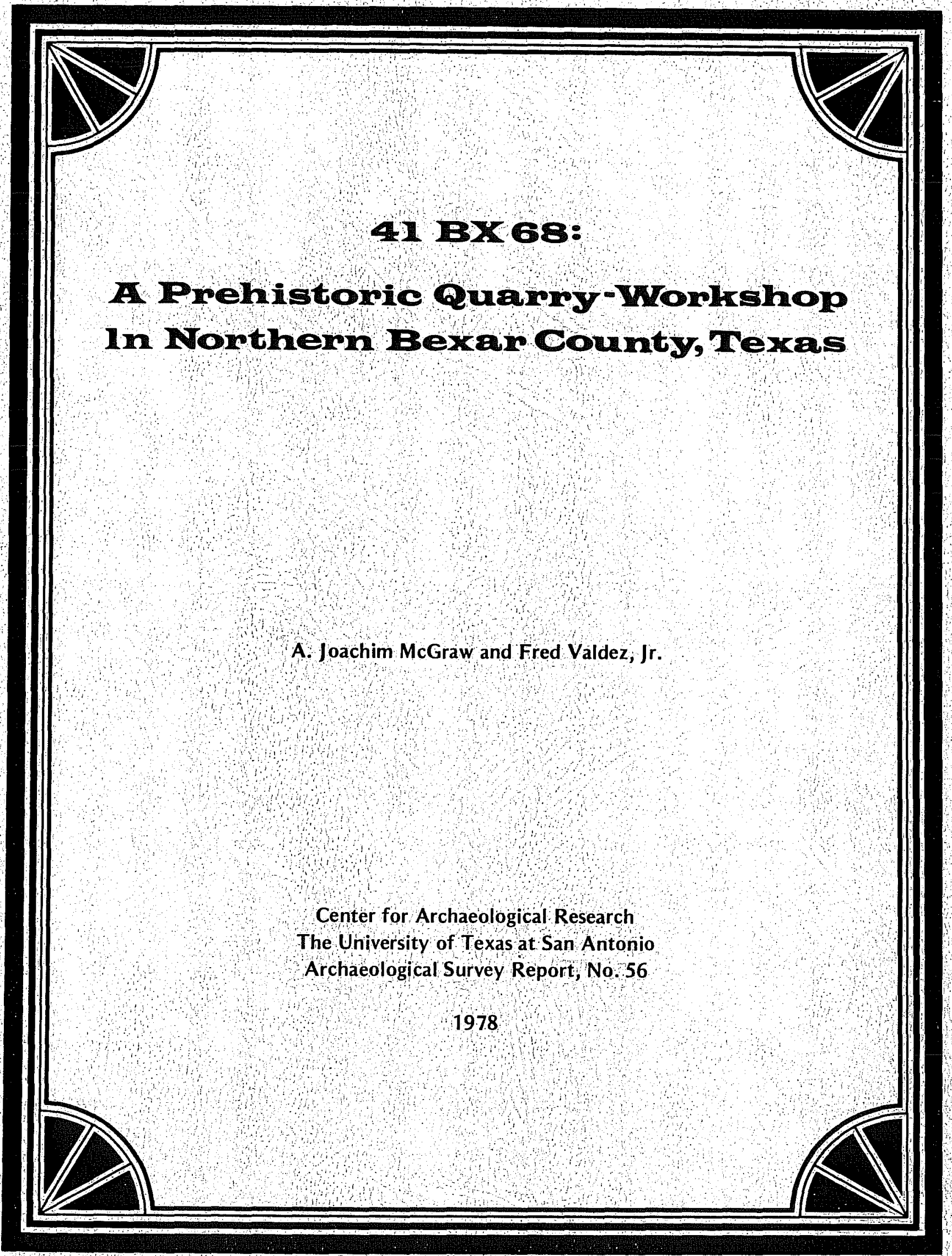


41 BX 68: A PREHISTORIC QUARRY-WORKSHOP IN NORTHERN BEXAR COUNTY, TEXAS

A. Joachim McGraw and Fred Valdez, Jr.

Center for Archaeological Research The University of Texas at San Antonio Archaeological Survey Report; No. 56

1978 
List of figures..................... i i

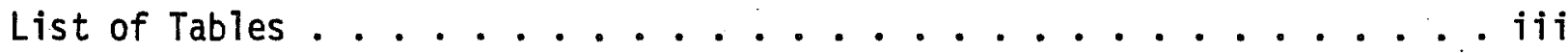
Acknowledgments...................... iv Introduction ...................... ] Previous Research..................... 1 Environmental Setting. ................. 4 Chronology of Prehistoric Habitation . . . . . . . . . . . 5

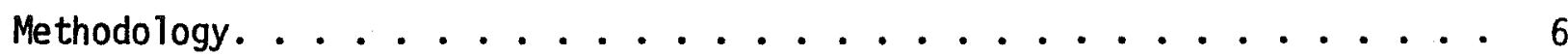
Site Investigations. ................... 11 Distributional Analysis of Lithic Materials. . . . . . . . . 15 Summary and Conclusions. . . . . . . . . . . . . . . 40 References Cited ................... 41 


\section{LIST OF FIGURES}

Figure

1. Site Location. . . . . . . . . . . . . . . . . . 2

2. View of Site..................... . . 3

3. Research Design. . . . . . . . . . . . . . . . 7

4. Contour Map of $41 \mathrm{BX} 68$. . . . . . . . . . . . . . . . 9

5. $200 \mathrm{~m}^{2}$ Grid/Selected Units . . . . . . . . . . . . . 10

6. Profile of TP-1, East Wall ................ . 13

7. Illustrations of Selected Artifacts. . . . . . . . . . . 14

8. Map of $25 \mathrm{~m}^{2}$, No. 8....................... 17

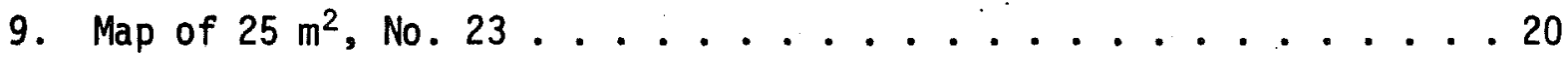

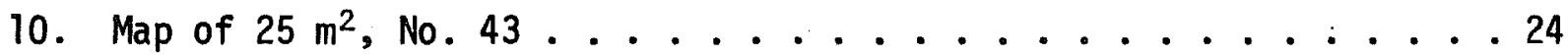

11. Map of $25 \mathrm{~m}^{2}$, No. 44 . . . . . . . . . . . . . . . . 26

12. Map of $25 \mathrm{~m}^{2}$, No. 50 . . . . . . . . . . . . . 30

13. Map of $25 \mathrm{~m}^{2}$, No. 59 . . . . . . . . . . . . . . . 32

14. Map of Control Square C-1................... 35

15. Map of Control. Square C-2. . . . . . . . . . . . . . . 37

16. Histograms Showing Comparisons of Selected Lithic Materials. . . . 39 


\section{LIST OF TABLES}

Table

Page

1. 41 BX 68; Artifact Description in Collection Square 8...... 18

2. $41 \mathrm{BX} 68$; Artifact Description in Collection Square $23 \ldots 21$

3. $41 \mathrm{BX} 68$; Artifact Description in Collection Square 43 ...... 25

4. 41 BX 68; Artifact Description in Collection Square $44 \ldots 27$

5. $41 \mathrm{BX} 68$; Artifact Description in Collection Square 50 ...... 31

6. $41 \mathrm{BX} 68$; Artifact Description in Collection Square $59 \ldots . . . .33$

7. 41 BX 68; Artifact Description in Collection Square C-1 ...... 36

8. $41 \mathrm{BX} 68$; Artifact Description in Collection Square $\mathrm{C}-2 \ldots \ldots$ 


\section{ACKNOWLEDGMENTS}

The writers wish to thank all those who made this report possible. Special thanks are due Mr. G. Fisher, owner of the property, for his friendly cooperation. Cristi Assad, technical staff assistant, spent long hours in the field and her enthusiasm and perceptive comments contributed to the success of the project. The investigation was conducted under the overall supervision of Thomas R. Hester, Ph.D., Director of the Center for Archaeological Research, The University of Texas at San Antonio, and Jack Eaton, Assistant Director. 
INTRODUCTION

During late February and early March of 1978, personnel from the Center for Archaeological Research, The University of Texas at San Antonio, conducted intensive mapping and limited subsurface testing of the prehistoric quarry-workshop site of $41 \mathrm{BX} 68$. Investigations of the site, located near the intersection of FM 1604 and Elm Creek in northern Bexar County (see Fig. 1), were conducted under the terms of a contract (Purchase Order No. 40-7442-8-426) with the Soil Conservation Service. Located near proposed Floodwater Retarding Structure 11, portions of the extensive site will soon be altered or critically damaged by modification.

Preliminary observations of the site indicated large areas were relatively undisturbed since the original aboriginal activity had taken place (Brown et al. 1977). Intact, relatively undisturbed concentrations of lithic debris were noted (see Fig. 2). The frequency, distribution and association of these materials were considered to be of unusual value in identifying intra-site activity areas. The intent of the current investigation was to formulate a preliminary description of the site and identify various aspects of lithic technological processes and their intra-site relationships in a prehistoric south central Texas quarry-workshop area.

\section{PREVIOUS RESEARCH}

As one of the most archaeologically studied counties in Texas, Bexar County has over 500 identified and recorded sites, to date, although many of these sites have been investigated at only a preliminary survey level with little sustained research. The identification, recording and analysis of these sites has been the direct result of an intensive program of public service archaeology initiated by the Center for Archaeological Research, The University of Texas at San Antonio.

The work surrounding $41 \mathrm{BX} 68$ is part of a major focus of study in northern Bexar County centered along Salado Creek and its tributaries in the area. Fawcett (1972) discusses the prehistoric significance of the locality in terms of areal inter-relationships while more recent reports have concentrated on site specificity. Recent investigations include Hester et al. (1974), Smith and McDonald (1975), Brown et al. (1977), Fox (1977), Jaquier et al. (1978), McGraw et al. (1977), McGraw and Valdez (1977a, 1977b), Gerstle et al. (1978) and Assad (1978).

Contrasted to the general interest in prehistoric sites within the study area generally, quarry-workshop sites in central and south Texas have been largely ignored, although they have been briefly discussed by Patterson (1975) and Kelly and Hester (1975a, 1975b). Quarry-workshop sites have received considerable attention in other parts of North America (e.g. Holmes 1894; Heizer and Treganza 1972; and see the bibliography in Hester and Heizer 1973).

There are several major archaeological sites in northern Bexar County, including $41 \mathrm{BX} 17$, the Granberg site; $41 \mathrm{BX} 22$, the Rogers site; $41 \mathrm{BX} 228$, Walker Ranch; $41 \mathrm{BX} 229$, the St. Mary's Hall site; $41 \mathrm{BX} 271$, the Granberg II site; and $41 \mathrm{BX}$ 300 , a large burned rock accumulation/occupation site. The importance of this area during prehistoric times has become evident through the analysis and identi- 
This page has been

redacted because it

contains restricted

information. 


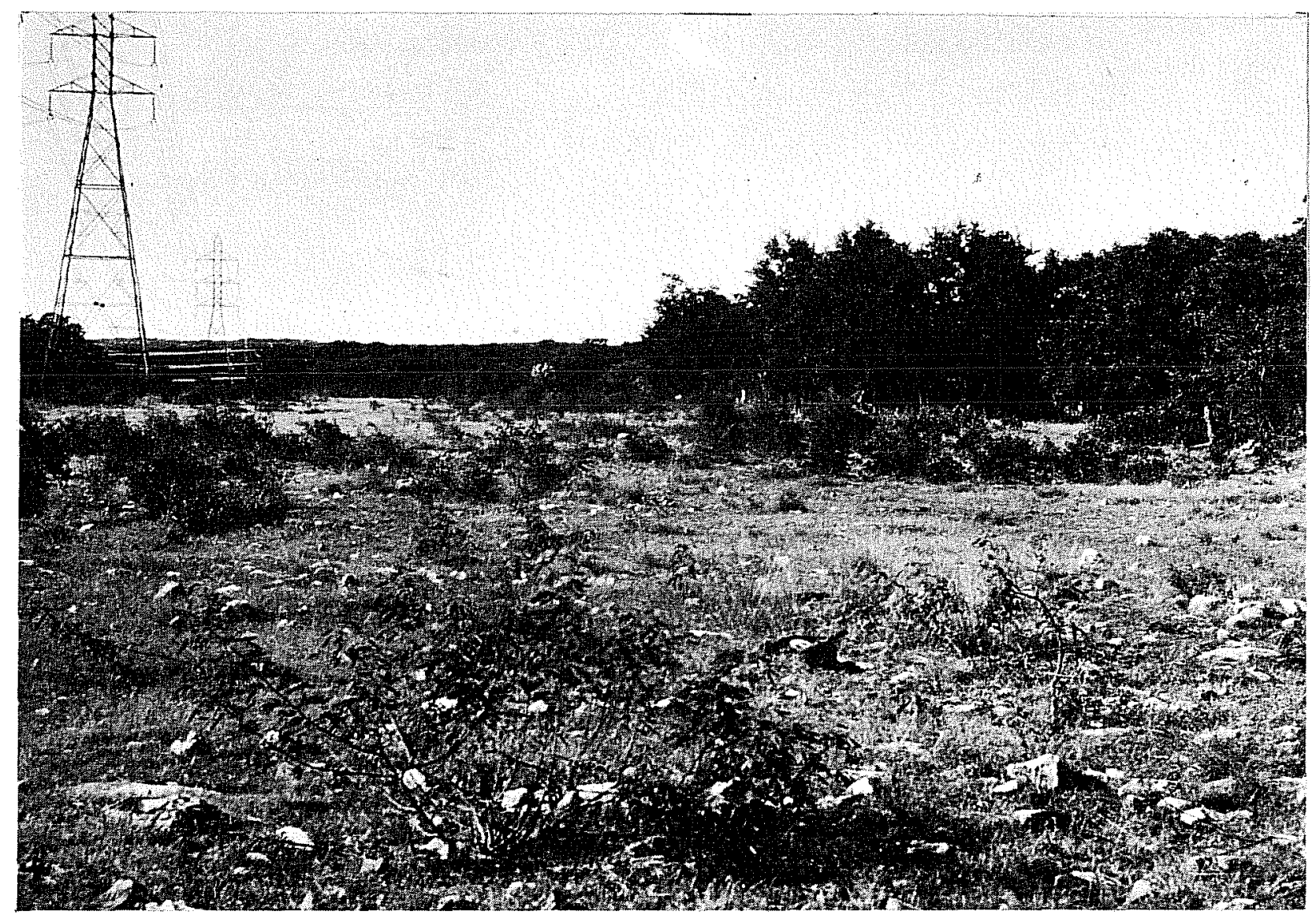

Figure 2. View of Site. 
fication of a large number and variety of aboriginal artifacts. The entire chronological sequence of south central Texas, from the Paleo-Indian tradition through the more recent Historic Indian periods, is represented within the general study area.

\section{ENVIRONMENTAL SETTING}

An elementary review of the more important environmental conditions within the study area will be discussed. For additional information the reader is referred to Fawcett (1972), Scurlock and Hudson (1973), Hudson et al. (1974), Gerstle et al. (1978) and McGraw et al. (1977).

\section{Topography}

Bexar County lies in the transition zone between the southern limits of the Edwards Plateau Escarpment and the northern rim of the South Texas Plains portion of the Gulf Coastal Plain. The drainage patterns for Bexar County run southward and southeastward. The major streams of the county are Cibolo Creek, Leon Creek, Medina River, Salado Creek and San Antonio River (Environmental Impact Statement-San Antonio 1977 [EIS-SA]). Characterized by prominent eroding 1 imestone uplifts and light, calcareous, soil cover, the northern area of the county is reflective of the Texas Hill Country. Elevations in northern Bexar County range from ca. 1250 feet above mean sea level on hilltops to below 700 feet (ms1) along drainage channels (McGraw and Valdez 1977b). 41 BX 68 is located in the general northern transition zone and the site environs are characteristic of the features mentioned above.

\section{Geology}

There are three distinct soil associations within the study area. However, not reflected in these soil types are complications resulting from local drainages in the form of redepositions, erosion, alluviums, etc. The three major soil associations are: Crawford-Bexar soils (moderately deep, stony soils over limestone); Tarrant-Brackett soils (shallow and very shallow soils over limestone); and Lewisville-Houston Black (terrace-associated, deep, calcareous soils in old alluvium (see Taylor et al. 1966). Six major rock types can be found in the Bexar County area. These include: hard limestone, mixed hard and soft limestones, clay, unconsolidated to consolidated sand, mixed sand and clay, and alluvium and terrace deposits (EIS-SA 1977). The alluvium and terrace deposits consist of a variety of lithologies which include consolidated and unconsolidated clay, silt, sand and gravel (ibid.). In the southern part of the county, the gravel deposits provide a basic source of chert. The northern section of Bexar County has numerous exposures of chert in the Edwards Limestone Formation. For the purposes of this report, chert refers to a wide range of materials in which are sometimes included "flint", "jasper" and similar crytocrystalline rocks. These rocks are fine-medium grained, semitransluscent, or opaque, with conchoidal fracturing properties (Wilmsen 1970). Hamilton et al. (1974) define chert as an opaque, bedded, massive chalcedony, usually dull grey to black in color. Chalcedony is the name given to compact varieties of silica comprised of minute quartz crystals with sub-microscopic pores. It should be noted the term "flint" is reserved for the black nodular variety of chalcedony commonly found in chalk (vs. the perculation-formed chert of limestone). 
Climate

Bexar County, with mild winters and moderately hot summers, can be described as subtropical. High and low record temperatures vary respectively from $106^{\circ}$ to $0^{\circ} \mathrm{F}$., while daily maximum and minimum temperature averages are $79.2^{\circ}$ and $53.1^{\circ}$ respectively (Taylor et al. 1966). Precipitation is usually evenly distributed throughout the year, averaging 27.84 inches per year. Record precipitation for Bexar County (maximum and minimum) is 52.28 and 13.70 inches, respectively. Rain in the form of thunderstorms falls in all seasons except winter and quite often results in flooding of local waterways and low water areas (McGraw et al. 1977). Snowfall in the Bexar County study area is rare. The winter season is dominated by northern winds while southeasterly Gulf winds. predominate during the summer. The period from the last spring freeze to the first freeze in fall averages 245 days (Taylor et al. 1966).

Flora and Fauna

The study area of Bexar County falls within portions of three biotic provinces as discussed by Blair (1950). These are the Balconian, Texan and Tamaulipan. A detailed study of the flora and fauna of Bexar County is beyond the scope and intent of this report. Additional information can be obtained from the following sources: Blair (1950), Davis (1974), Fawcett (1972), Gould (1969), McGraw and Valdez (1977b) and Taylor et al. (1966).

\section{CHRONOLOGY OF PREHISTORIC HABITATION}

The archaeology of south central Texas generally and of the study specifically is only broadly defined. Sites located near 41 BX 68 are usually near past or present water resources, the now-intermittent drainages that flow southward through the rocky limestone elevations characteristic of northern Bexar County. Hester (1976) discusses the characteristics of these sites in detail although his emphasis is on occupation rather than quarry-workshop sites. The latter, in the same area, have been mostly ignored and poorly studied. Reflecting the technological leavings of the early inhabitants of south Texas, quarry-workshop sites in northern Bexar County are scattered over large areas where outcroppings of chert cobbles occur along the exposed Edwards Limestone Formation.

A detailed discussion of aboriginal activities in this region is beyond the scope of this report and this study will identify only highlights of the prehistoric chronology. While artifact evidence in the region suggests activity dating to 9200 B.C., very little is known of the varied and complex cultures that once inhabited the area for millennia in the past. Four major time periods are represented by sites near the study area and they are defined as the PaleoIndian, the Archaic, Late Prehistoric and the Historic.

Paleo-Indian projectile points are found scattered in localities throughout south Texas. This presumably represents a Plains-derived 1ithic phenomenon with distinct cultural systems. Hester (1968, 1974 and 1977) discusses and presents distributional data on this period. Throughout most of south Texas, Plainview and Golondrina points are the dominant forms and are reflected in the occupations of such major sites as 41 BX 229, the St. Mary's Hall site and 41 VT 15, the Johnston-Heller site along the Guadalupe River drainage (see Hester 1977). 
Following the Paleo-Indian period and preceding the Archaic, there now appears evidence of a transitional phase occuring in south and central Texas. Lithic traits include corner notched and triangular dart points and stemmed points termed Gower (Sollberger and Hester 1972).

Although Archaic sites comprise the majority of prehistoric remains in the region, the long span of time that is associated with the Archaic period is poorly understood. Recent investigations suggest vast diversities once existed in south central and south Texas cultures identified with the Archaic. Heterogeneous settlement patterns and areally unique lithic tool kits indicate the Archaic may have been composed of numerous bands of hunters and gatherers with specific territorial limits. Hester (1976) suggests these bands were characterized by specific adaptations to various ecosystems and localized environments. Archaic sites are assumed to reflect the technological leavings of small groups who used a highly mobile broad spectrum foraging strategy in response to seasonal scheduling in the availability of numerous floral and faunal resources (Reher 1977).

The Archaic in south central and south Texas is still poorly understood al though major inroads have been made in the last decade. A status report of specific aspects of the Archaic lifeway has been presented by Hester (1976), and this not only provides an up-to-date interpretation of Archaic features but also discusses the problems and complexities of the study. However, one facet of the Archaic lifeway that remains poorly known is the lithic procurement system. Large Archaic period quarry-workshops, such as 41 BX 68, are known along the edge of the Edwards Plateau, but few have been adequately studied (e.g. Katz 1978).

The best known chronological unit in south Texas is the Late Prehistoric, ca. A.D. 500/1000-A.D. 1500. The Late Prehistoric reflects a number of cultural modifications which often abruptly modified artifact assemblages. The bow and arrow, pottery, and in some localities, agriculture, were primary characteristics of the period. Fawcett (1974) suggests that Edwards points were the predominant type of projectile point from the Edwards Plateau Region to the north and west of the south central Texas region. For a more detailed synthesis of the Late Prehistoric, see Hester and Hill (1975) and Hester (1975).

The Historic period of south Texas archaeology (A.D. 1500) is generally defined as the period of post-European contact. The time span saw the decline of indigenous groups who were decimated by disease, missionization or assimilation. Intrusive Plains Indians such as the Comanche and Apache temporarily filled the void left by earlier groups. For an elaboration and a detailed discussion of these and other groups, the reader is referred to Newcomb (1961).

\section{METHODOLOGY}

The investigation of $41 \mathrm{BX} 68$ was based upon a systematic analysis directed toward: (1) the location and identification of intra-site activities; (2) a preliminary assessment primarily through surface examination of the site's content and importance; (3) the detailed recording of such information for future research; and (4) recommendations for any further work at the site (see Fig. 3 ). The observation of lithic materials such as debris concentrations was noted not 


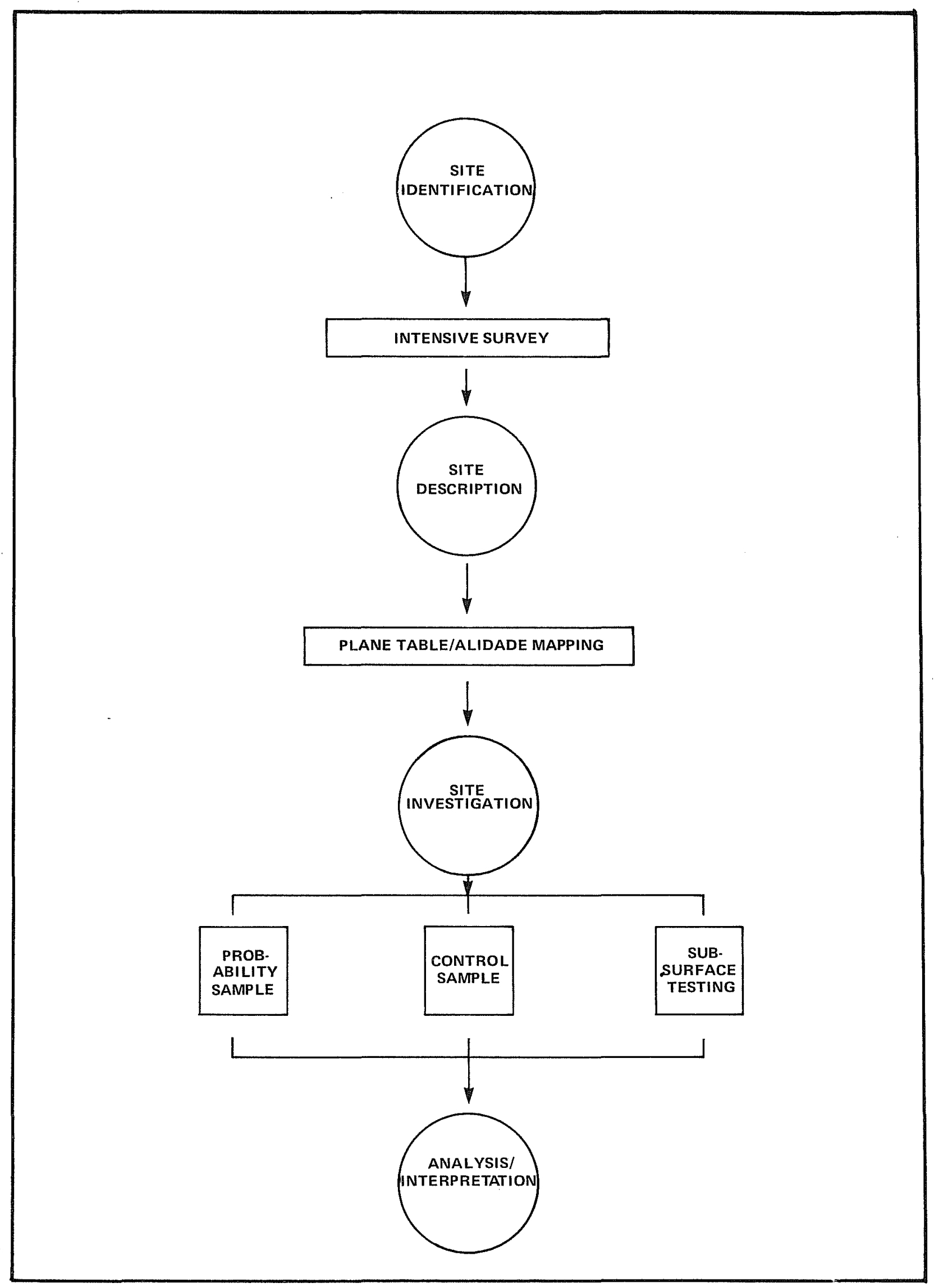

Figure 3. Research Design. 
only to define boundaries but to locate areas of specific activity. The presence or absence of particular cultural materials as well as elevations and distances from a water source were also particular considerations (McGraw 1977).

Data from 41 BX 68 has been recorded on standard field forms used by the Center for Archaeological Research. Black and white photographs and color slides were taken as a visual record of operations. All collected materials were placed in plastic or paper bags and labeled as to collected area, site number, date, type of collection and collector's name. All artifacts were processed at the UTSA Archaeology Laboratory. The assessments presented in this report are based upon an analysis of field maps, artifacts, photographs, field forms and notes. Detailed data is on file with the Center for Archaeological Research.

Site investigations were divided into three distinct phases during the two weeks of field operations: (1) the completion of an accurate site map utilizing an alidade and plane table; (2) the detailed and intensive mapping of materials in selected areas; and (3) 1 imited subsurface testing to supplement surface information. An intensive survey prior to the commencement of testing operations suggested the site extended along the eastern terrace of Elm Creek in excess of $450 \mathrm{~m}$ and eastward, away from the drainage, at least $400 \mathrm{~m}$ (see Fig. 4). Because of time limitations and the large site area (in excess of $400 \mathrm{~m}^{2}$ ) an entire map of the site area was considered unfeasible. Surface observations suggested that a detailed contour map could be made of the lithic debris representing a distinctive concentration of chert materials within the large scatter. This concentration presumably represents the densest activity area of the lithic scatter and occupies the higher elevations of the terrace. The site maps as presented in Figs. 4 and 5 thus indicate an area of ca. $200 \mathrm{~m}^{2}$ and represent the most identifiably intense activity locality at the site. A north-south grid line designated N1000 E1000 was established in this area to facilitate mapping.

The second phase of site investigations revolved around the problem of obtaining a clear perspective of intra-site activities and lithic debris distributions when confronted with finite temporal limitations and the generally unworkable, large site dimensions.

Because of these factors, the researchers concluded a $10 \%$ random probability sample through detailed mapping of selected areas would present a relatively undistorted view of surface material distribution during the time allowed. To complement the collected data, two separate judgment (control) samples were also taken; one $25 \mathrm{~m}^{2}$ grid system based on $25 \mathrm{~m}$ intervals was imposed over the area previously chosen for detailed plane table/alidade mapping. Each $25 \mathrm{~m}^{2}$ was assigned a sequential number ranging from 1 to 64 . Six numbers (a $10 \%$ sample) were chosen using a Random Numbers Table (Redman 1974) and the associated units were then intensively mapped to record any identifiable cultural materials within their boundaries. The actual mapping of each square was done with the aid of a $30 \mathrm{~m}$ tape and the use of a surveyor's compass established on diagonal corners of each unit to facilitate recording.

To supplement the present site investigations, limited subsurface examination in the form of a $1 \mathrm{~m}^{2}$ was excavated in the immediate vicinity of the earlier excavated Shovel Test 5 (Brown et al. 1977). This area was the only identified locality within the site that reflected any soil depth. Subsurface frequency 


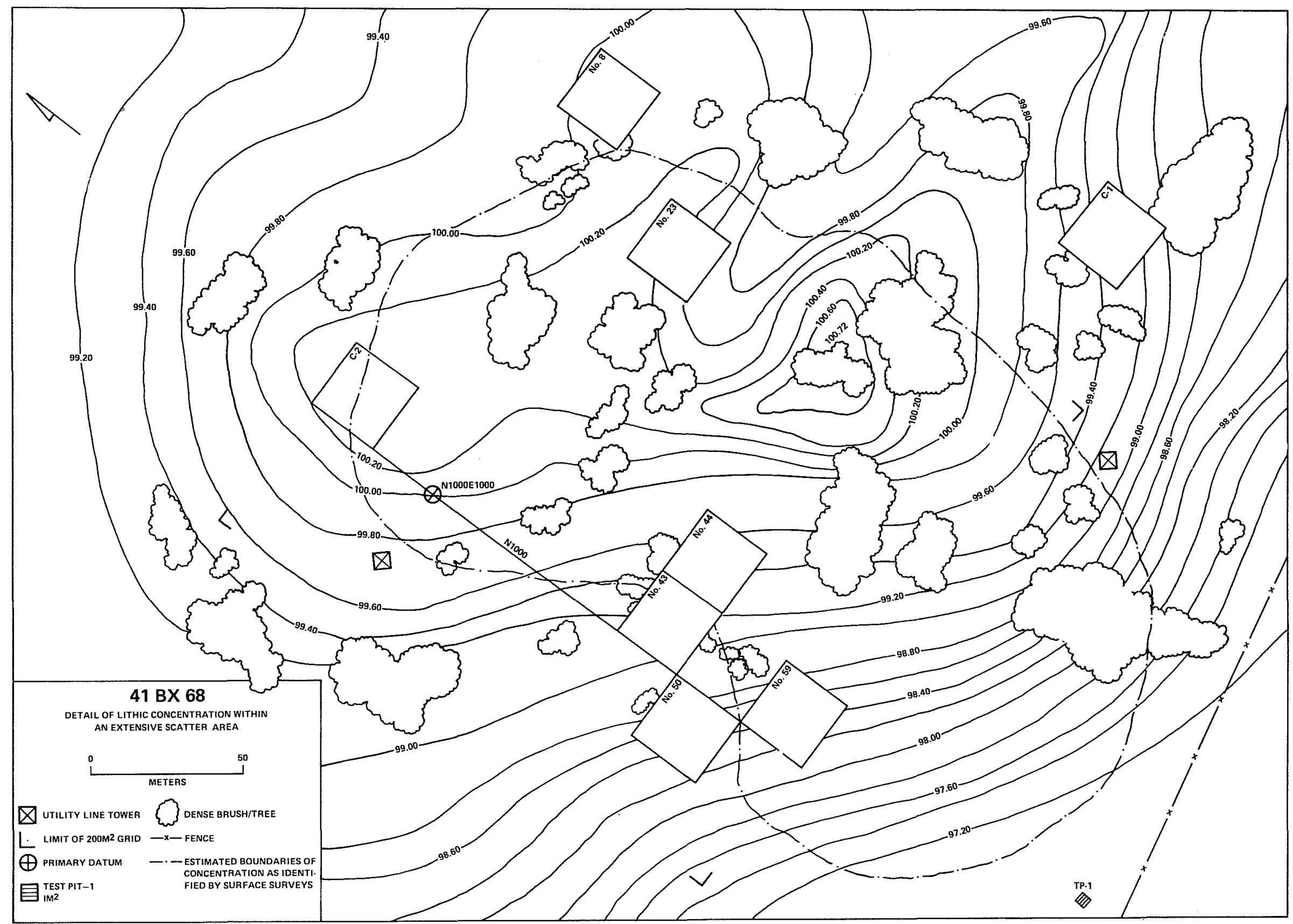

6

Figure 4. Contour Map of 47 BX 68. 


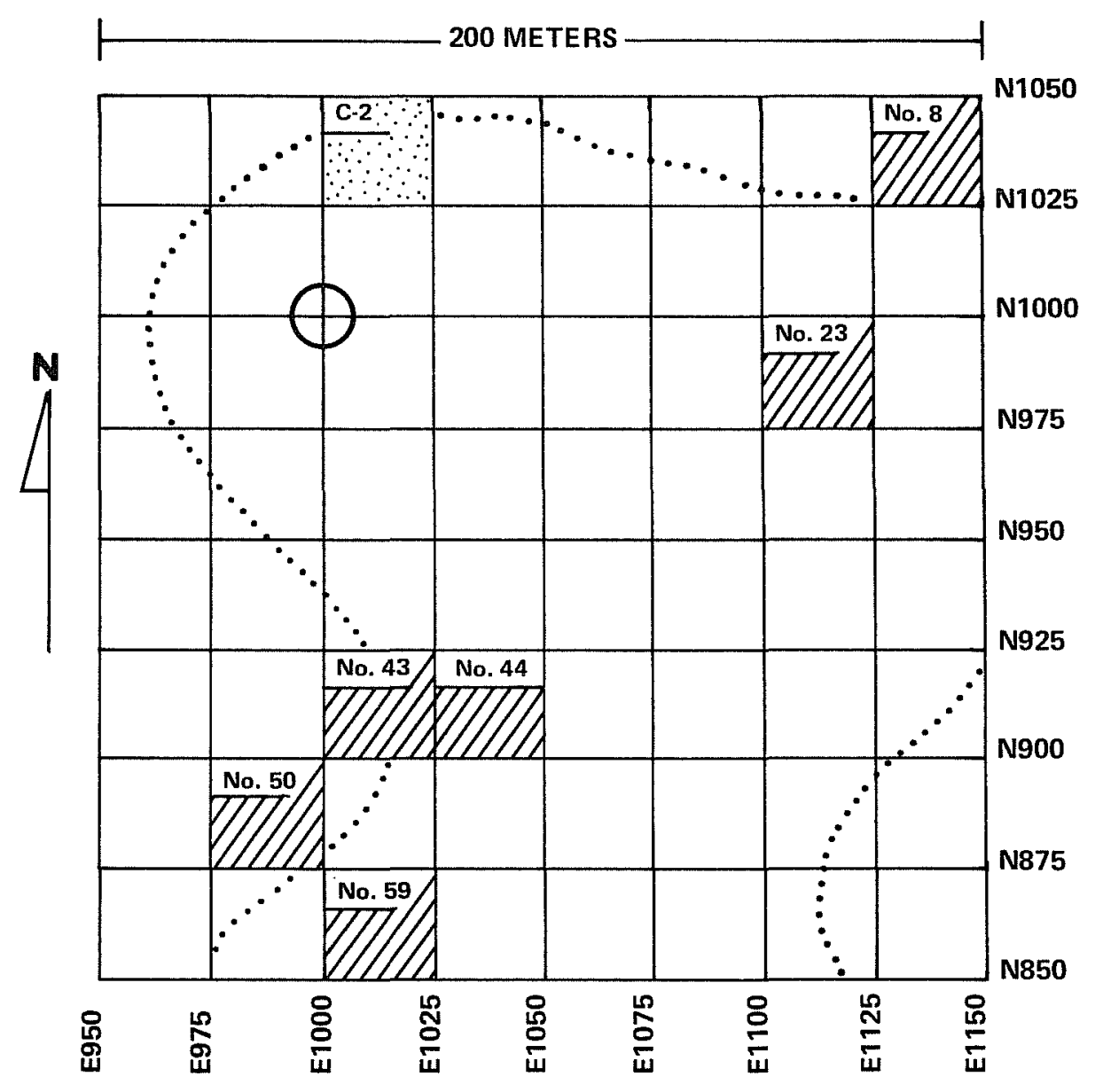

$\theta$ primaty datum

SAMPLED UNIT

CONTROL UNIT

(JUDGMENT SAMPLE)
ESTIMATED BOUNDARY OF LITHIC CONCENTRATION AS IDENTIFIED BY INTENSIVE SURFACE SURVEY

Figure 5. $200 \mathrm{~m}^{2}$ Grid/Selected Units. 
of artifacts, their horizontal and vertical distribution, and soil characteristics were primary considerations during the examination.

\section{SITE INVESTIGATIONS}

Preliminary reports (Hester et al. 1974; Brown et al. 1977) described the site as lying atop a large, flat ridge high above the east bank of Elm Creek. Recent alteration in the form of a utility/powerline right-of-way has cut through one of the heaviest concentrations of lithic debris in the area. The site has also presumably been further damaged through the efforts of local relic collectors.

An interior survey to establish concentrations and general site boundaries found the prehistoric quarry-workshop area to extend more than $450 \mathrm{~m}$ east and north away from the main concentration area near the powerline right-of-way and also over $400 \mathrm{~m}$ south. Lithic debris in the form of chips, flakes and cores littered the surface throughout the locality. Occasional unifaces, crude biface fragments and a surprising number of trimmed and/or utilized flakes were also observed. Similar materials have been noted elsewhere and not limited to this locality (Holmes 1894:9-13; Patterson 1975:19-20; Assad 1978).

As noted earlier, the large physical dimensions of the site combined with dense brush, limited manpower and lack of investigative time precluded a detailed examination of the entire 7 ithic scatter. Preliminary reports, substantiated by current intensive operations, indicated a more intense concentration of lithic materials covering an area ca. $200 \mathrm{~m}^{2}$ atop the higher elevations of the site. This area was chosen as a feasible area from which to approach further field studies of the chert workshop activity area.

Mapping of the concentration was accomplished by a plane table and alidade and a series of 10 mapping stations. A permanent datum was established at an arbitrary point designated NT000 E1000 and all calculations were based on a metric scale. Following the reading of 72 elevation points in this area, the N1000 El000 point was used to establish a north-south axis which was incorporated into a $200 \mathrm{~m}^{2}$ arbitrarily divided into 64 manageable $25 \mathrm{~m}^{2}$ units. To save time, each point of the $200 \mathrm{~m}^{2}$ was not laid out on the surface; instead, a $10 \%$ random probability sample was chosen as described earlier in methodology and these individual units (numbers $8,23,43,44,50$ and 59) were established with the help of a plane table and alidade, a $30 \mathrm{~m}$ tape, a surveyor's compass, string and flagging tape. While a slight degree of inaccuracy was noted between the surveyor's compass and the alidade, the error was not sufficient to affect the overall analysis. All lithic debris, burned rocks and lithic tools were recorded in these units.

It was recognized that due to the small sample size, a biased view of the site might be obtained. For a comparison of the overall distribution and frequency of materials at the site, two control samples, also $25 \mathrm{~m}^{2}$ units, were recorded. These judgment samples ( $\mathrm{C}-1$ and $\mathrm{C}-2$ ) were located in a previously unsampled portion of the $200 \mathrm{~m}$ grid and also outside of the identified concentration. The results of these efforts are presented in Figures 8 through 15 and corresponding Tables 1 through 8 . Figure 16 presents histograms of frequencies and distributions of selected materials from sampled units. 
To complement the surface information, a $1 \mathrm{~m}^{2}$ subsurface examination was conducted adjacent to Shovel Test 5, excavated during the earlier preliminary survey. Although Brown et al. (1977) had excavated a series of $50 \mathrm{~cm}^{2}$ shovel tests, only Shovel Test 5 revealed any soil or cultural depth.

Designated Test Pit 1 (TP-1), the $1 \mathrm{~m}^{2}$ was excavated by trowels and all materials were screened through 1/4-inch wire mesh. Vertical levels were dug in $10 \mathrm{~cm}$ increments and all materials were placed in plastic or paper bags for further laboratory analysis. The unit was excavated to a depth of $40 \mathrm{~cm}$ and four soil strata were observed. From the surface to a depth of 3 to $4 \mathrm{~cm}$, an unconsolidated medium brown surface fill was noted. Beneath this and lying atop a heavily compacted dark brown soil was a cultural layer of 1 ithic debris composed of numerous primary, secondary and tertiary flakes, chips and cores. While the cores and core fragments were scattered between 6 and $26 \mathrm{~cm}$, an extensive debris layer was noted between 2 and $5 \mathrm{~cm}$. Beneath the heavily compacted dark brown soil was a less compacted, medium brown clayey soil, unusually moist. Several cores, patinated flakes and other lithic fragments were overlain by large limestone rocks. Between 24 and $28 \mathrm{~cm}$, a transition occurred with a reddish-brown soil overlaying calcareous limestone gravels, the latter ranging in size from .5 to $1.5 \mathrm{~cm}$. Large 1 imestone slabs and deteriorating limestone rocks were found beneath this soil layer to a depth of $40 \mathrm{~cm}$. The limit of artifact depth was reached through the test unit at $\mathrm{ca} .28 \mathrm{~cm}$ (see Fig. 6).

Definition of Materials

The description and definition of lithic materials and reduction processes are beyond the capabilities of this limited study and this brief section cannot hope to discuss all of these various aspects in depth. For the purposes of this report, only elements which pertain to 41 BX 68 will be discussed. Distinguishing attributes of major artifact and debris categories will be noted and various characteristics discussed as to their significance. Selected artifacts are illustrated in Fig. 7.

For the practical use of this study, many artifact and debris categories will be described based on the degree and type of retouch. Modification of debris material generally takes the form of trimming, or retouch, referring to modification of debris for the purposes of edge alteration, strengthening or sharpening. The result of this action is small flake scars on dorsal and/or ventral sides and ends. The extent of these scars across the width of the debris can be termed marginal, semi-invasive or invasive. Invasive, in this report, is defined as retouch scars extending more than $1 / 3$ of the length across the material's surface. For definitions of general 1 ithic categories identified at 41 BX 68 , this section has divided lithic materials into two general categories: (1) cores and lithic debris and (2) unifacial and bifacial artifacts.

Cores and Lithic Debris

Cores may briefly be defined as a piece of siliceous stone used as raw material for a variety of lithic reduction processes; they exhibit at least one flat surface from which one or more pieces of 1 ithic debris have been detached and do not exhibit any bulbs of percussion. Core tools describe cores which reflect marginal or invasive retouch and/or wear (observable alteration of an edge caused by utilization). 


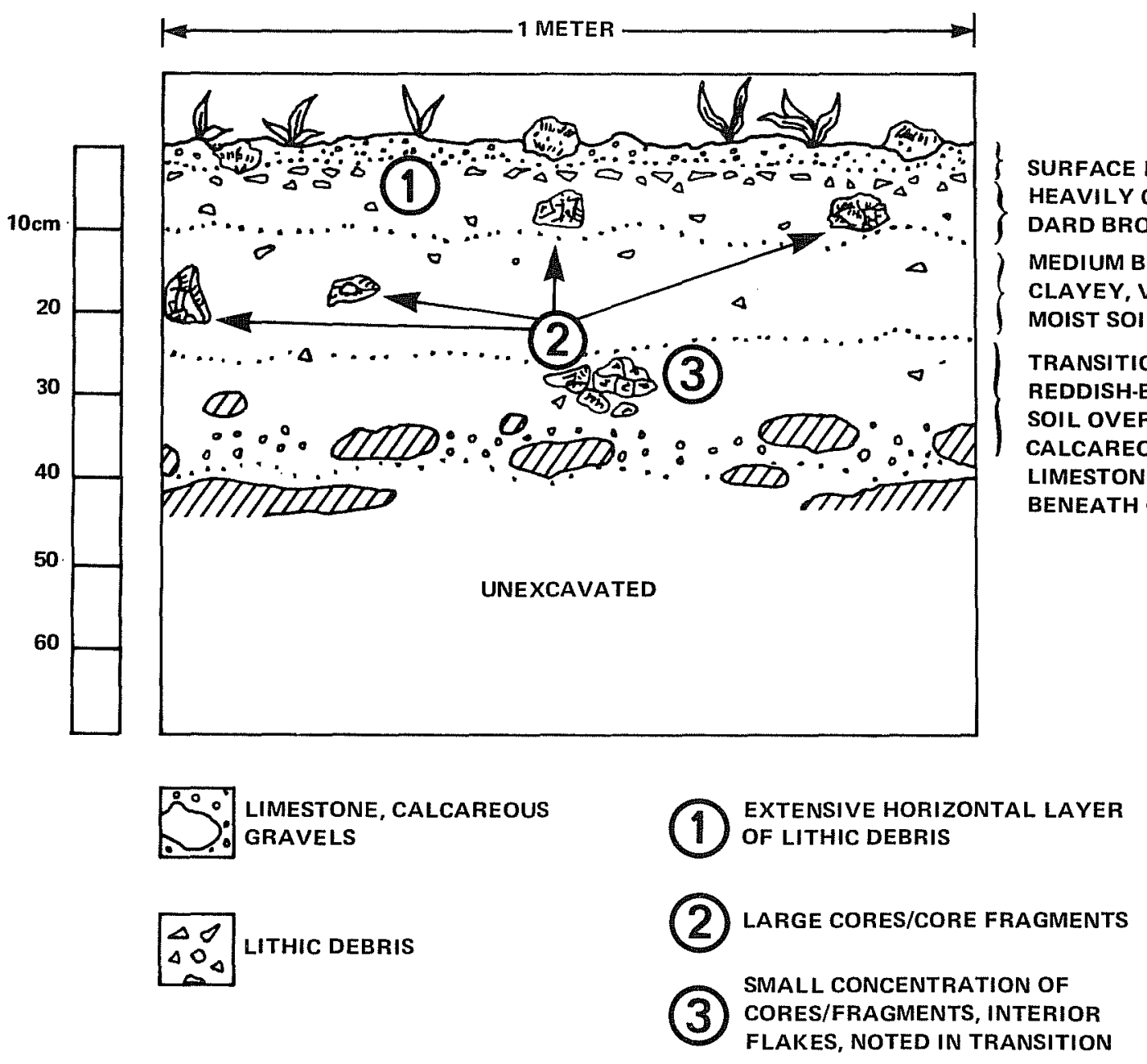

Figure 6. Profile of TP-1, East Wall. 

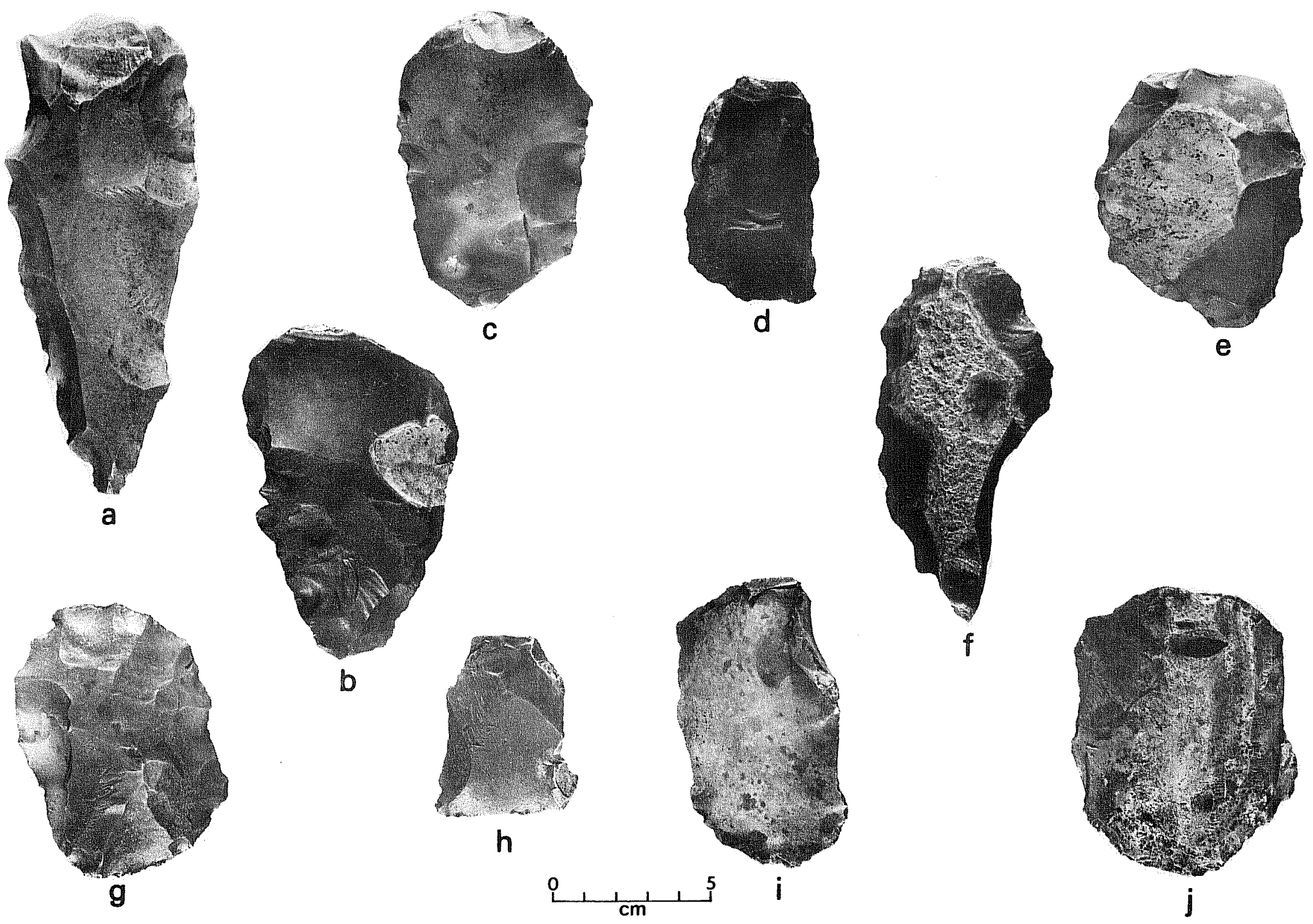

Figure 7. Illustrations of Selected Artifacts. a, crude biface, possible quarry blank; b, partially finished thick biface with side and end trimming; $c$, partially bifaced scraper, extensive end retouch; d, rectanguloid uniface with extensive end modification; e, ovoid biface trimmed along dorsal and ventral sides; $f$, thick biface fragment; $g$, ovoid uniface, extensive retouch along dorsal and ventral sides; $h$, rectanguloid uniface, extensive end modification; $i$, uniface with steep retouch along dorsal edges; $j$, uniface with extensive end modification of dorsal edge. 


\section{Lithic Debris}

Lithic debris is briefly defined as the collection of smaller pieces of stone, flakes and chips detached from a core during reduction processes. Through high-resolution examination of various attributes, a single flake can often be associated to one of a series of sequential stages of manufacture, which often reflects the technique formerly employed.

Three general categories of flakes are identified in this report, dependent upon the amount of cortex on the exterior surface: (1) primary flakes, with cortex completely covering the exterior, or dorsal, surface; (2) secondary flakes, with some cortex and (3) tertiary, or interior, flakes having no cortex on their dorsal surfaces. Flakes include a variety of types and sizes of platforms, or remnants of the original striking platform on the core. Flake platforms identified in this study are usually single-faceted, reflecting no prior retouch in the form of abrasion to build a prepared platform.

For the purposes of this report, the categories of chips and chunks are defined as shatter fragments distinguished by size, less than $1 \mathrm{~cm}$ and more than $1 \mathrm{~cm}$, respectively.

Unifacial and Bifacial Artifacts

These artifacts reflect trimming (retouch) on dorsal and/or ventral surfaces and may be grouped into such categories as gouge-like tools, scrapers, projectile points and other more crudely made, larger bifaces including preforms, quarry blanks and knife-like bifaces. The term uniface in this report refers only to extensively modified implements distinctly altered on one surface from the original shape of the debitage. For a more complete description of terms and a discussion of lithic reduction processes, the reader is referred to crabtree (1972).

\section{DISTRIBUTIONAL ANALYSIS OF LITHIC MATERIALS}

Site Characteristics

It has been fairly well established that quarry sites can be recognized by decortification flakes and occupation sites by secondary flakes (Kelly and Hester 1975b:13). What has not been established are the distributional phases presumed to have occurred in prehistoric quarry-workshops during: (1) decortification and preforming, (2) thinning and shaping and (3) sharpening and retouch. Gunn and Mahula (1977) have approached this problem through functional site analys is based on Sollberger Distributions (Gunn et al. 1976). This final report, based on biased data and often dealing with missing information, cannot define functional areas of $41 \mathrm{BX} 68$ but will instead make only general observations based on artifact identification in $25 \mathrm{~m}^{2}$ units. Gunn and Mahula (1977) suggest that specific phases of reduction processes can be isolated because flakes of each successive phase will be progressively smaller. Assuming this to be true and noting the skewed data based primarily on surface materials, it would appear $41 \mathrm{BX} 68$ is an indiscriminately littered 1ithic scatter with flakes of the phase three variety mixed among clusters of cores, core fragments and tertiary flakes. The extensive materials recovered in subsurface tests of TP-1 support this observation. 
Data from the site indicates a broad spectrum of workshop activity, involving not only core reduction but presumed proximity-related tertiary activities as reflected by the distribution of trimmed and/or utilized flakes within artifact clusters. Cores were often found in debitage clusters adjacent to trimmed flakes, suggesting related activities occurring at the same time in the same area. Reworked flakes in these clusters usually reflected dorsal (1ess often ventral) trimming or utilization, most of ten in the form of marginal or semiinvasive retouch along the flake sides. Clusters of flakes were often composed of distal secondary or tertiary flake fragments. Very few triangular or lipped flake platforms were observed, and the most common platform throughout was a single-faceted, flat, unabraded platform. Few irregular blade fragments were noted. Cores scattered throughout the site were often fragmentary or expended but in all cases reflected multiplatformed reduction. No projectile points were noted during the investigation, although this statement is based on biased negative evidence; the site has been known to relic collectors for years. Large, crude biface fragments constituted less than five percent of the collection samples, and the general ratio of debitage to completed tools was low.

The most intense horizontal level of artifact debris, as reflected by subsurface testing and local erosion, appears buried between 8 to $11 \mathrm{~cm}$ across the length of the site. Subsurface examination of TP-1 revealed an almost solid layer of debitage at $\mathrm{ca} .10 \mathrm{~cm}$. The profile of TP-1 reflected surface fill and two distinct soil layers above a calcareous transition zone at ca. $25 \mathrm{~cm}$. The largest frequency of flakes was concentrated within the upper $10 \mathrm{~cm}$, al though a small concentration of cores and patinated flakes were recovered within a reddish-brown transition zone at ca. $32 \mathrm{~cm}$. Data from all surface mapped $25 \mathrm{~m}^{2}$ units is presented in Figures 8 through 15. It should be noted that to conserve space, various abbreviations were used, and a brief key is presented below. Each artifact was numbered consecutively in each square as it was identified, and further supplementary information on individual materials can be found on adjacent Tables 1 through 8.

Key to Abbreviations Used in Mapping $25 \mathrm{~m}^{2}$ Units

$\mathrm{CF}$ - Core fragment

$U$ - Uniface

$\mathrm{CH}$ - Chunk/chip

$B R$ - Burned rock

C - Core

$X C$ - Expended core

B - Biface

\& - Bush, tree

BC - Battered cobble

CT - Core tool

F - Flake 


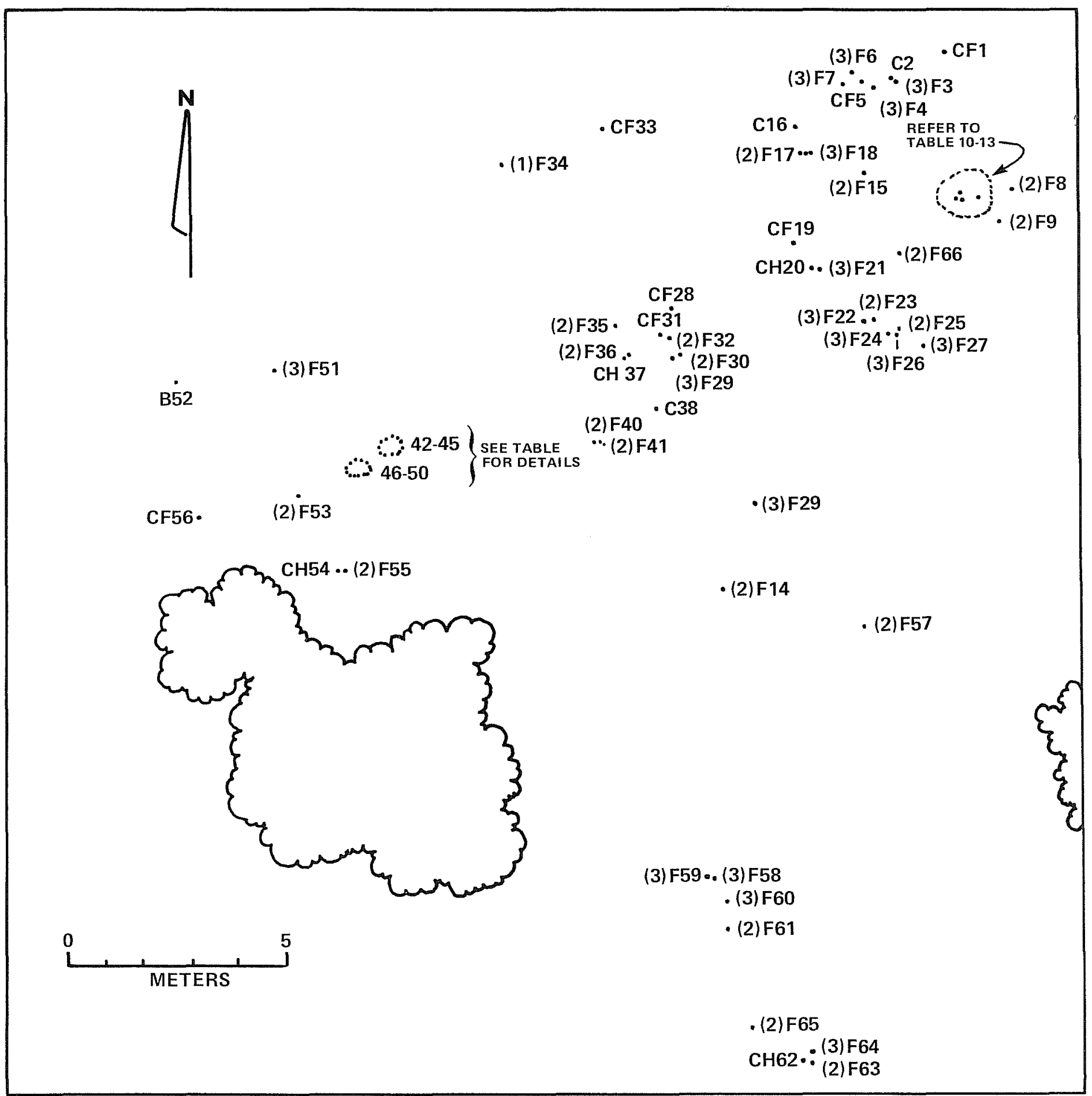

Figure 8. Map of $25 \mathrm{~m}^{2}$, No. 8. Distribution of cultural materials in random probability sample. Refer to page 16 and Table 1 for explanation of artifact designations. 
TABLE 1. 41 BX 68; ARTIFACT DESCRIPTION IN COLLECTION SQUARE 8

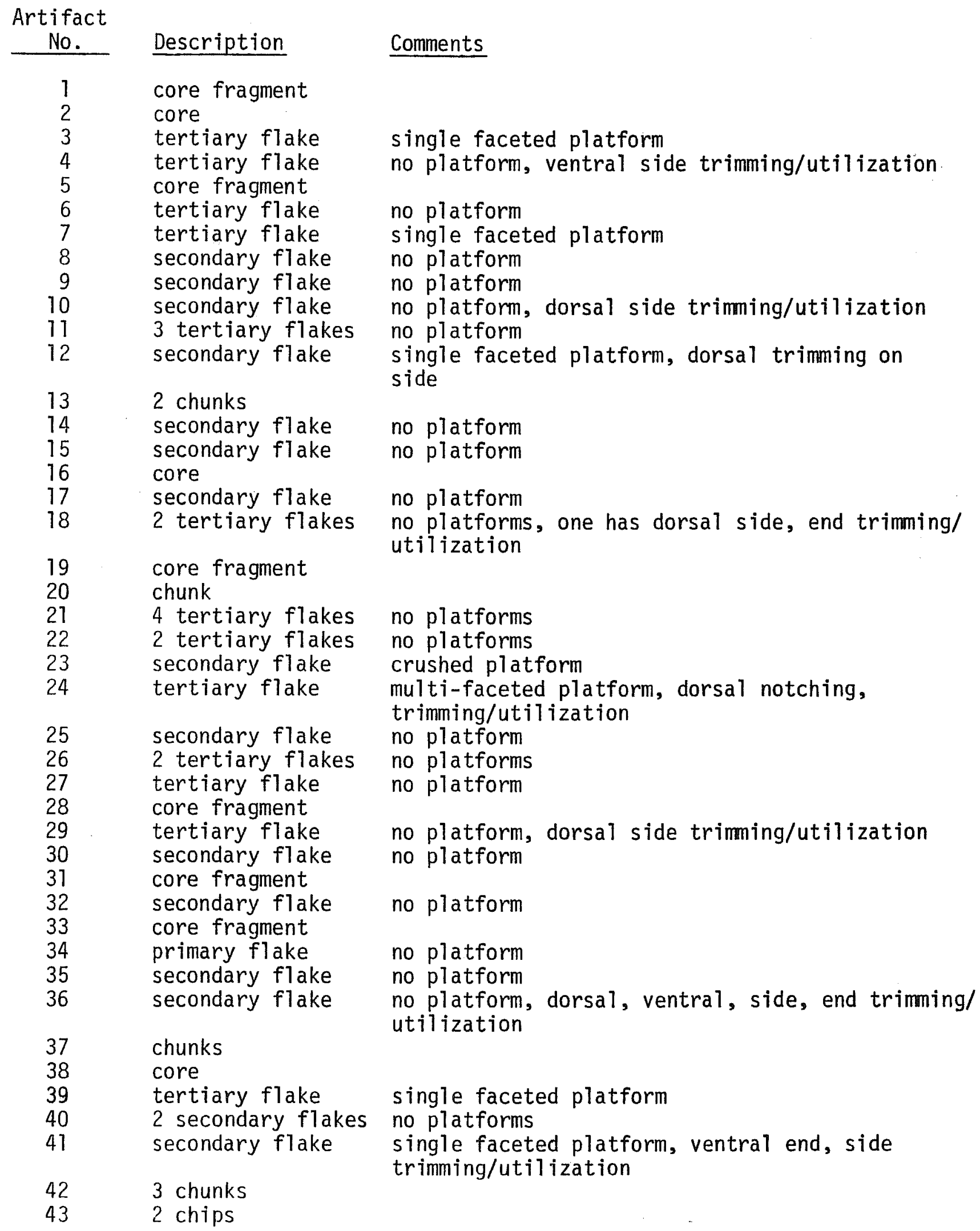


TABLE 1. (continued)

\begin{tabular}{|c|c|c|}
\hline $\begin{array}{c}\text { Artifact } \\
\text { No. } \\
\end{array}$ & Description & Comments \\
\hline 44 & core fragment & \\
\hline 45 & secondary flake & no platform \\
\hline 46 & chip & \\
\hline 47 & 2 tertiary flakes & no platform \\
\hline 48 & secondary flake & single faceted platform \\
\hline $\begin{array}{l}49 \\
50\end{array}$ & $\begin{array}{l}\text { secondary flake } \\
\text { chunk }\end{array}$ & no platform \\
\hline & secondary flake & no platform \\
\hline $\begin{array}{l}51 \\
52\end{array}$ & $\begin{array}{l}\text { tertiary flake } \\
\text { biface }\end{array}$ & $\begin{array}{l}\text { no platform } \\
\text { marginally retouched, crude }\end{array}$ \\
\hline $\begin{array}{l}52 \\
53 \\
54\end{array}$ & $\begin{array}{l}\text { secondary flake } \\
\text { chunk }\end{array}$ & $\begin{array}{l}\text { marginally retouched, crude } \\
\text { no platform }\end{array}$ \\
\hline 55 & secondary flake & $\begin{array}{l}\text { single faceted platform, dorsal side trimming/ } \\
\text { utilization }\end{array}$ \\
\hline 56 & core fragment & \\
\hline 57 & secondary flake & no platform \\
\hline 58 & tertiary flake & lipped, single faceted platform \\
\hline 59 & tertiary flake & no platform \\
\hline 60 & tertiary flake & $\begin{array}{l}\text { single faceted platform, ventral trimming/ } \\
\text { utilization }\end{array}$ \\
\hline 61 & secondary flake & $\begin{array}{l}\text { no platform, extensive ventral side, end } \\
\text { trimming/utilization }\end{array}$ \\
\hline $\begin{array}{l}62 \\
63 \\
64 \\
65 \\
66\end{array}$ & $\begin{array}{l}2 \text { chunks } \\
\text { secondary flake } \\
\text { tertiary flake } \\
\text { secondary flake } \\
2 \text { secondary flakes }\end{array}$ & $\begin{array}{l}\text { no platform } \\
\text { single faceted platform } \\
\text { no platform } \\
\text { no platforms }\end{array}$ \\
\hline
\end{tabular}


- (1)F110

(3)F114 - CF113

- (1)F111

- (1)F112

-CF109

(2)F108

(1) F107

- (3)F106

- (2)F100

. (2)F101

- (2)F102

B86.. (3) F87

(2) $\mathrm{F80}$

(2) F81 $\therefore$ (1)F82

BR90-93

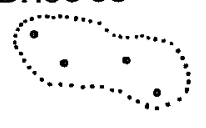

. (3) F99

- (2)F103

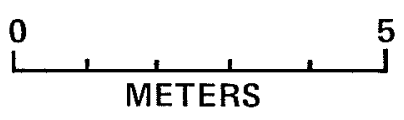

- (3)F98

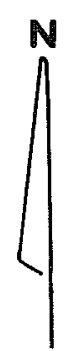

METERS
(3)F98

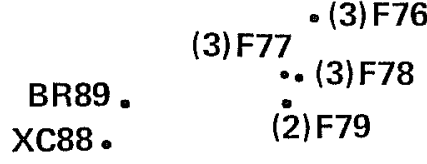

$\because \cdot \mathrm{CH} 63$

(3) F61-62

$$
\text { BR57 •.XC58 }
$$

(2) F5் CंF56
(2) F55

. (1)F50

- (1)F48 - CF49 XC39
- CF94

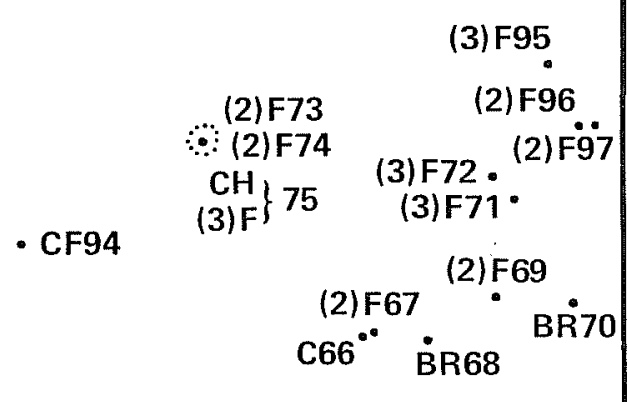

- BR65

\author{
CF54 \\ (2) F52 $\stackrel{\text { CH53 }}{\text { (3) F51 }}$
}

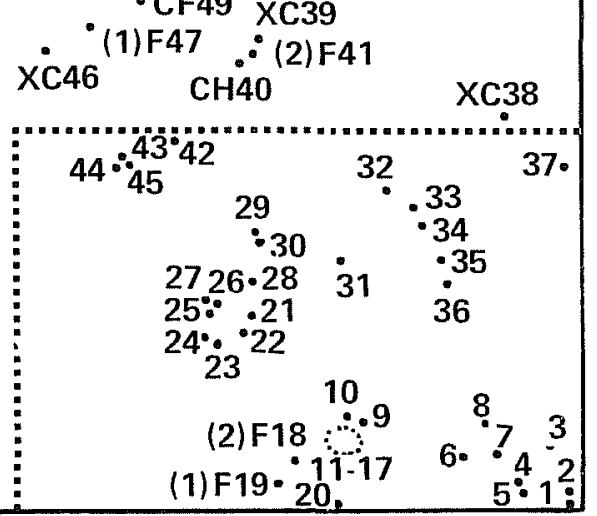

Figure 9. Map of $25 \mathrm{~m}^{2}$, No. 23. Distribution of cultural materials in random probability sample. Refer to page 16 and Table 2 for explanation of artifact designations. 
TABLE 2. 41 BX 68; ARTIFACT DESCRIPTION IN COLLECTION SQUARE 23

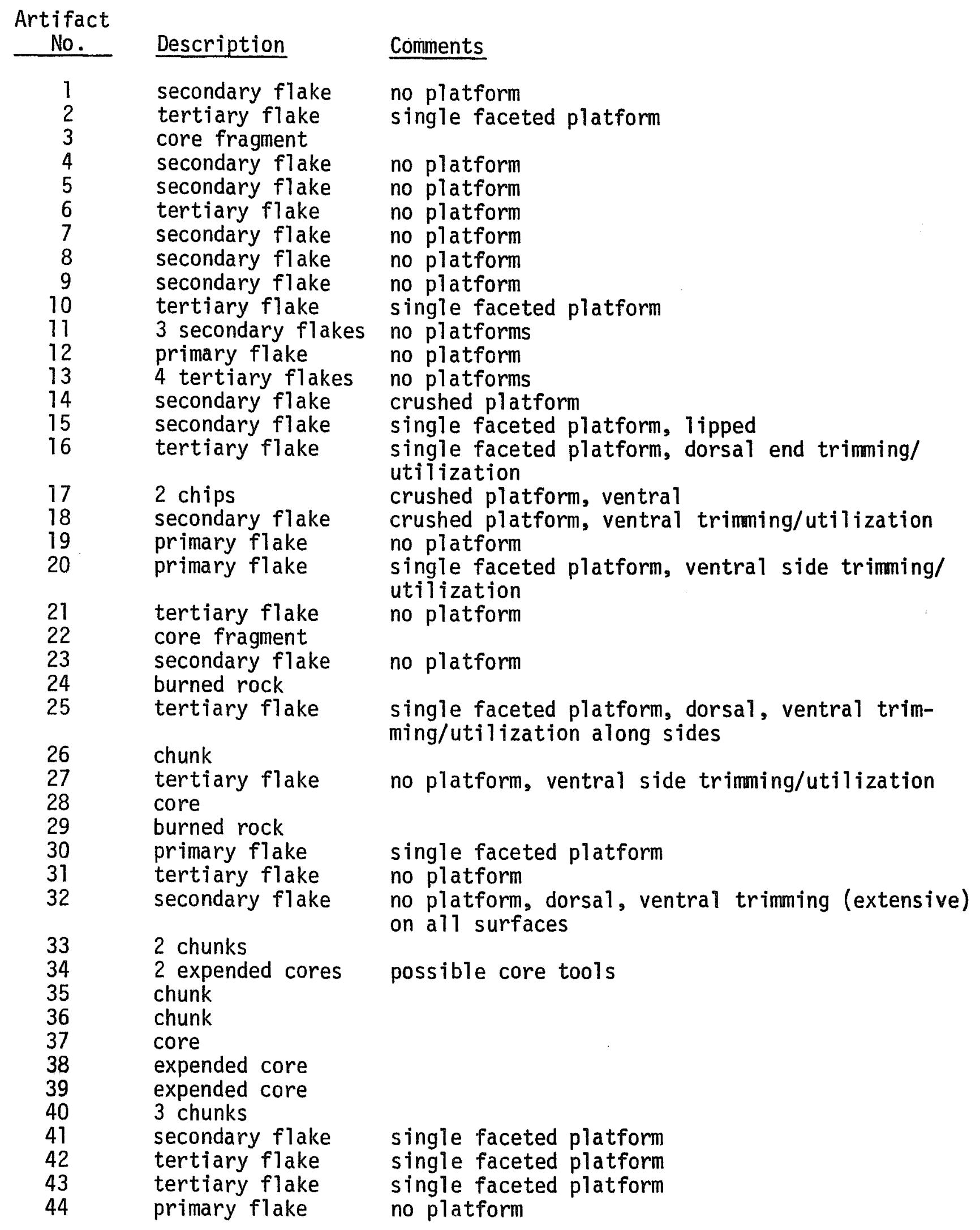


TABLE 2. (continued)

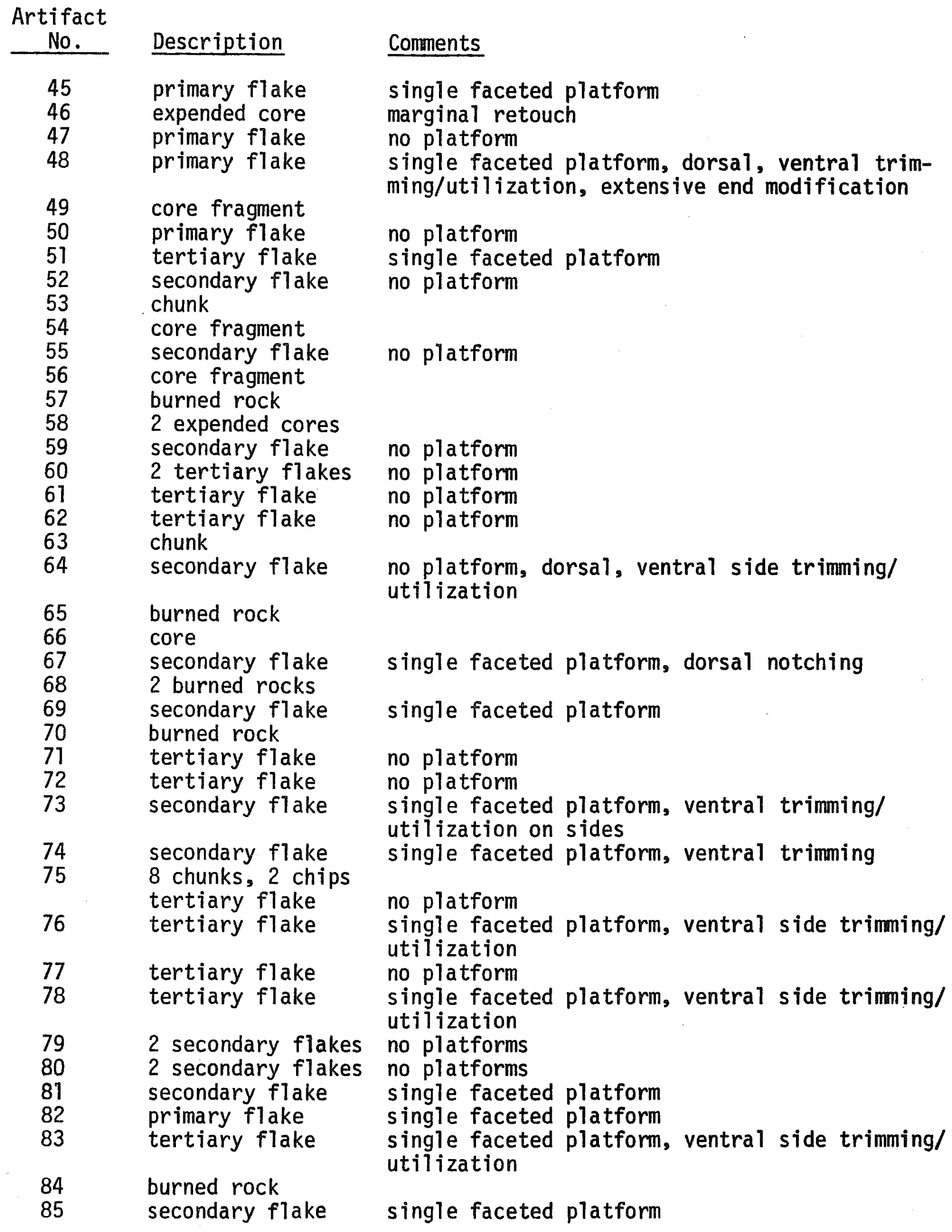


TABLE 2. (continued)

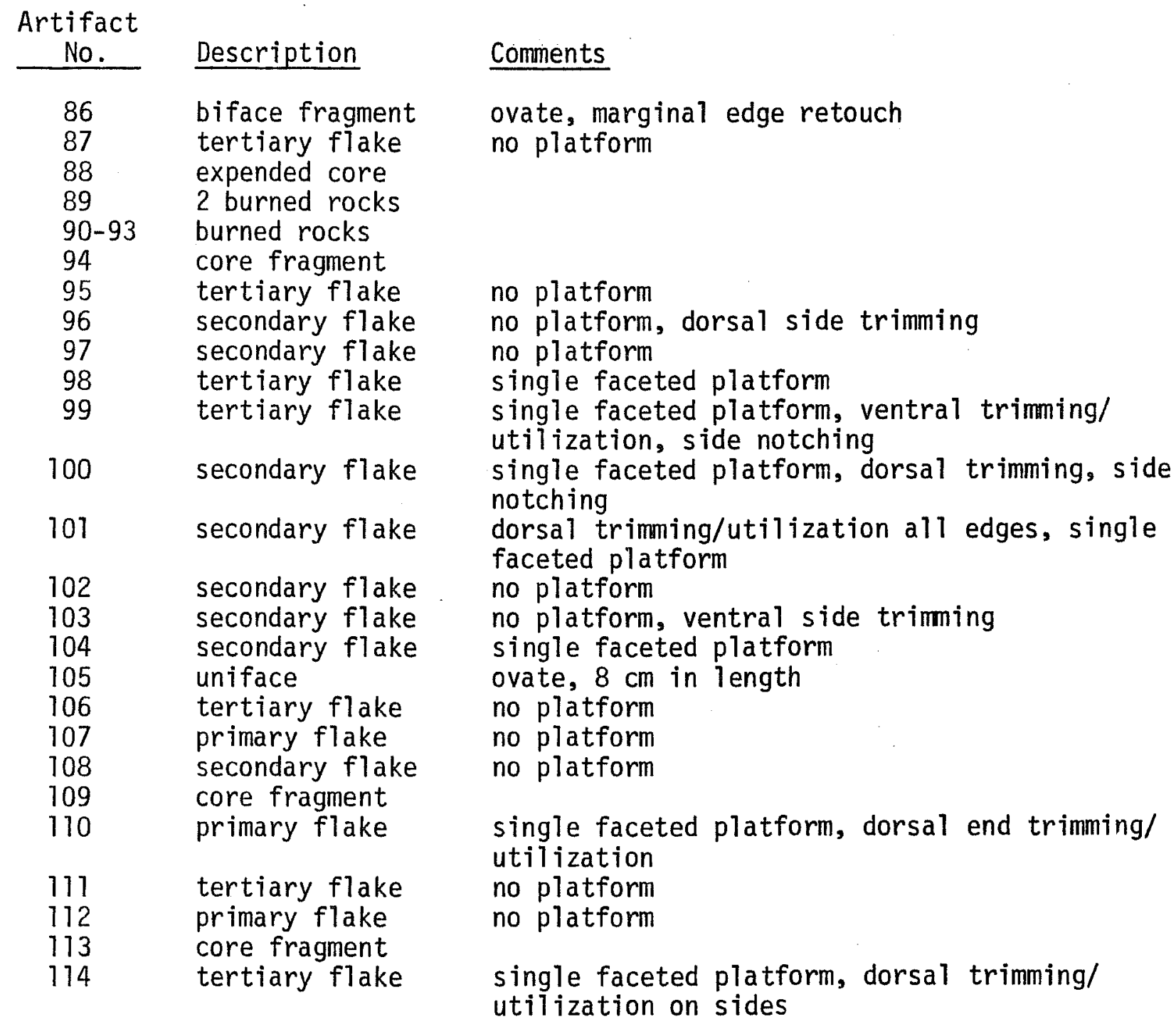


1

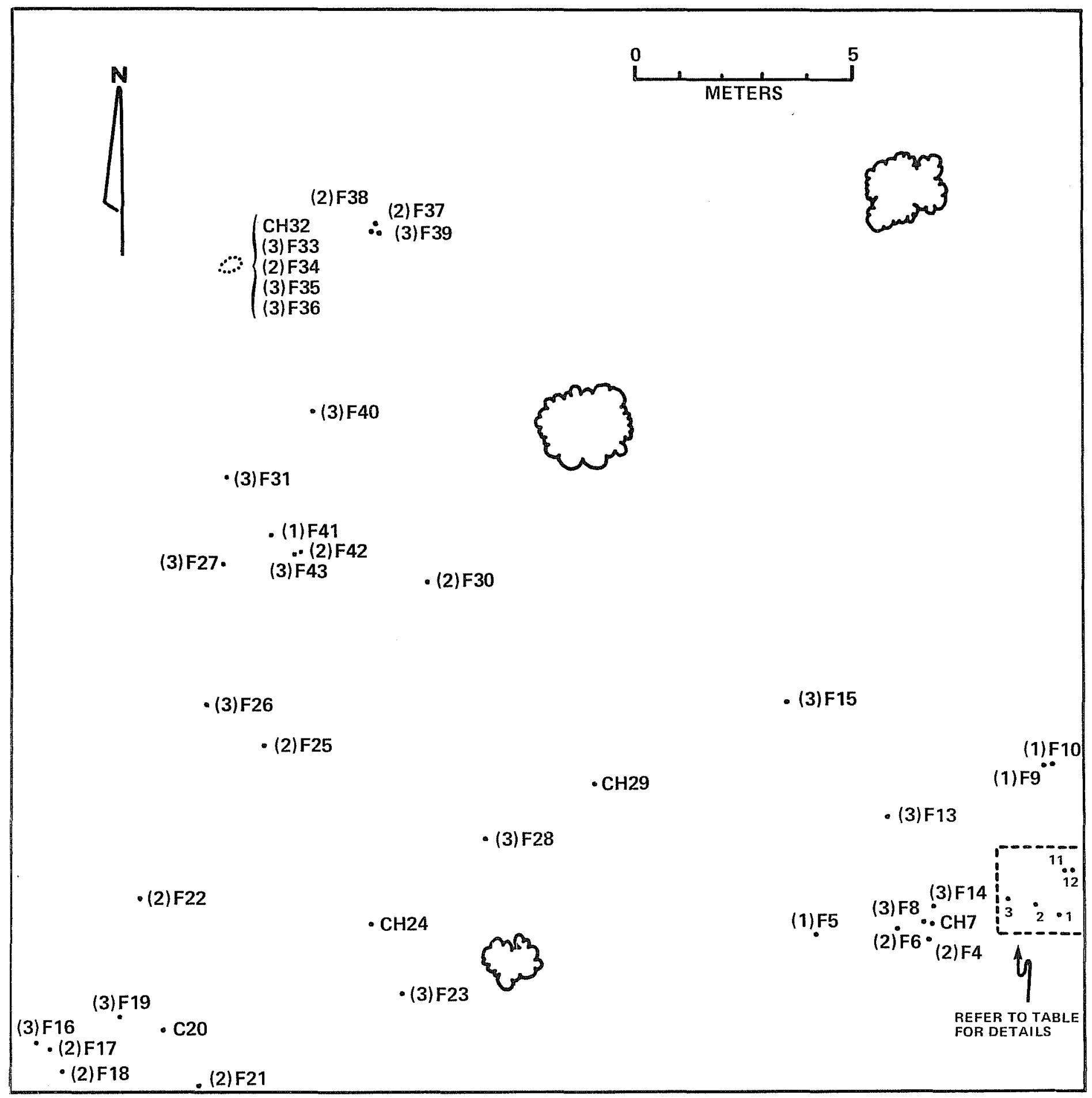

Figure 10. Map of $25 \mathrm{~m}^{2}$, No. 43. Distribution of cultural materials in random probability sample. Refer to page 16 and Table 3 for explanation of artifact designations. 
TABLE 3. 41 BX 68; ARTIFACT DESCRIPTION IN COLLECTION SQUARE 43

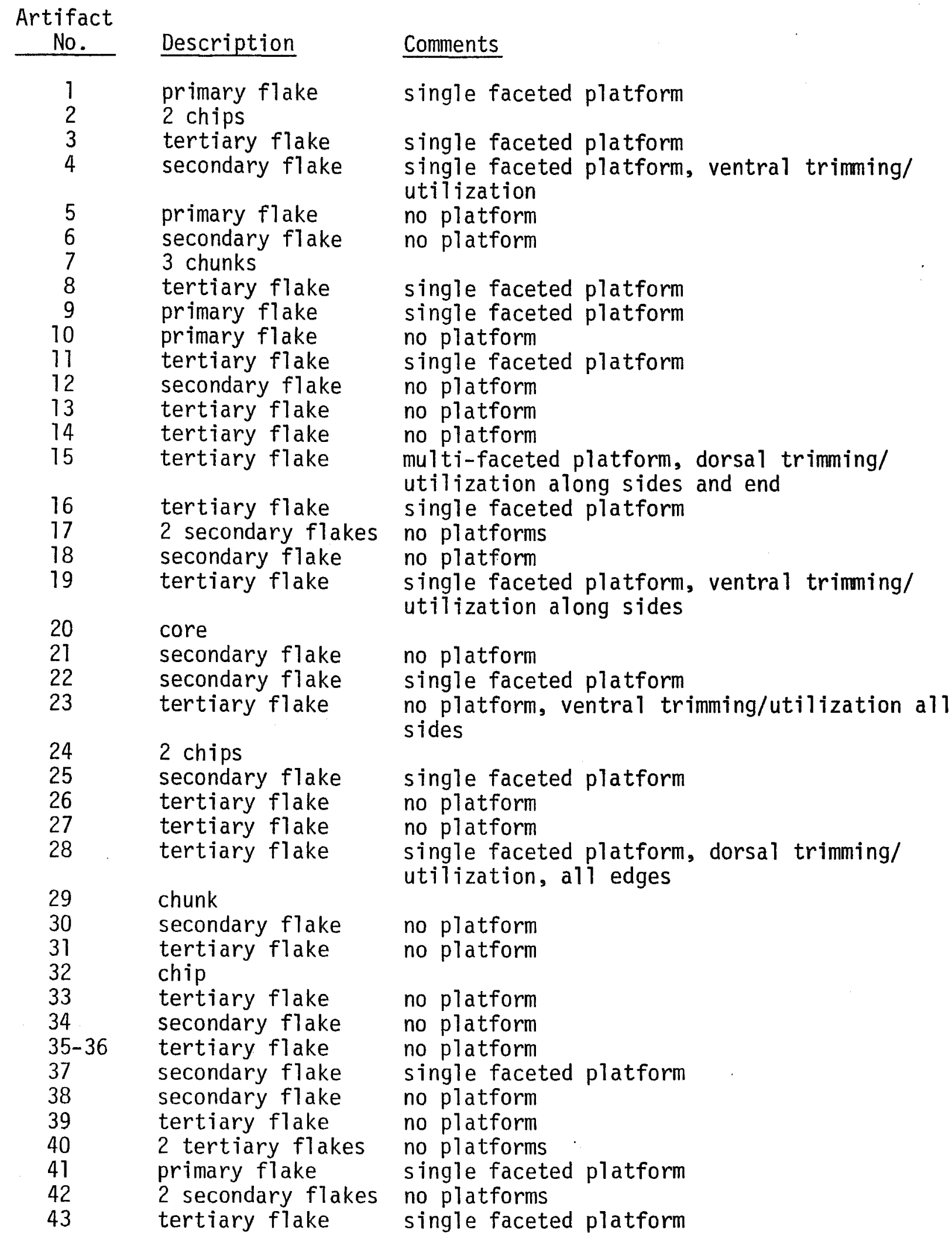




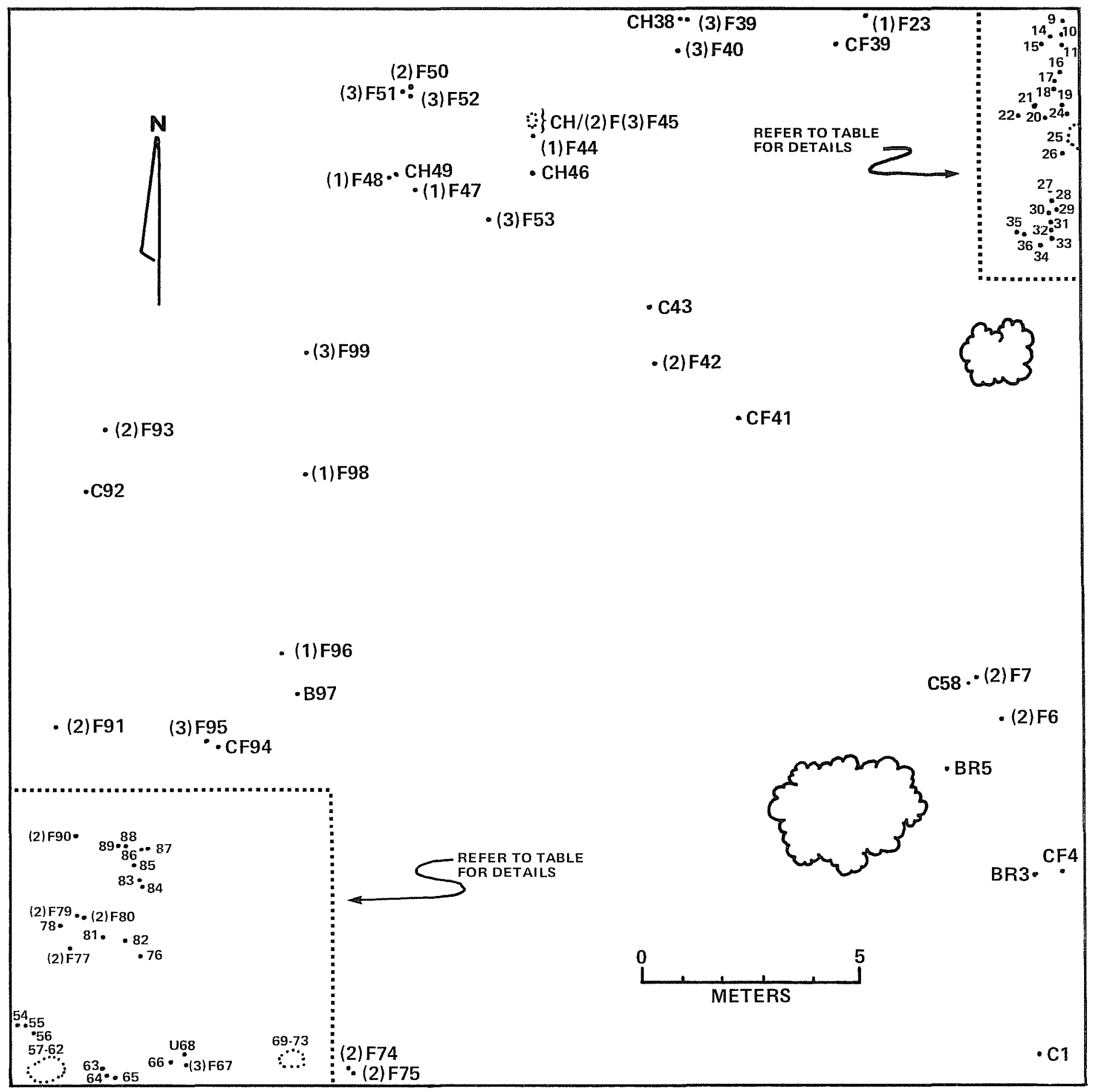

Figure 11. Map of $25 \mathrm{~m}^{2}$, No. 44. Distribution of cultural materials in random probability sample. Refer to page 16 and Table 4 for explanation of artifact designations. 
TABLE 4. 41 BX 68; ARTIFACT DESCRIPTION IN COLLECTION SQUARE 44

Artifact

No.

$\begin{array}{ll}\text { No. } & \text { Description } \\ 1 & \text { core } \\ 2 & \text { core } \\ 3 & \text { burned rock } \\ 4 & \text { core fragment } \\ 5 & \text { burned rock } \\ 6 & \text { secondary flake } \\ 7 & \text { secondary flake } \\ 8 & \text { core fragment } \\ 9 & \text { lithic concentration: } \\ & \quad \text { primary flake } \\ & \text { 3 secondary flakes }\end{array}$

5 tertiary flakes

4 chips

3 chunks single faceted platform, marginal retouch on dorsal, ventral sides single faceted platform, dorsal side trimming/utilization

no platform

no platform

multi-faceted platform, trimming/utilization of dorsal end single faceted platform, dorsal end trimming (3) no platforms no platform, dorsal trimming/utilization single faceted platform, ventral side trimming/utilization

no platforms

no platforms

single faceted platform, lipped, possibly pressure flakes

no platforms

single faceted platform

no platforms

single faceted platform

single faceted platform

no platform

no platform

no platform

no platform

single faceted platforms

no platforms

single faceted platform

multi-faceted platform tertiary flake chip core chunk 
TABLE 4. (continued)

\begin{tabular}{|c|c|c|}
\hline $\begin{array}{c}\text { Artifact } \\
\text { No. }\end{array}$ & Description & Comments \\
\hline $\begin{array}{l}26 \\
27\end{array}$ & $\begin{array}{l}\text { secondary flake } \\
\text { core }\end{array}$ & no platform \\
\hline 28 & tertiary flake & no platform \\
\hline 29 & tertiary flake & $\begin{array}{l}\text { no platform, dorsal, ventral side trimming/ } \\
\text { utilization }\end{array}$ \\
\hline 30 & core fragment & \\
\hline 31 & tertiary flake & no platform \\
\hline 32 & primary flake & no platform \\
\hline 33 & secondary flake & single faceted platform \\
\hline 34 & secondary flake & no platform \\
\hline 35 & uniface & $\begin{array}{l}\text { ovoid, } 9 \mathrm{~cm} \text { in length, dorsal, ventral end, } \\
\text { side trimming/utilization }\end{array}$ \\
\hline 36 & core fragment & \\
\hline $\begin{array}{l}37 \\
38\end{array}$ & $\begin{array}{l}\text { core fragment } \\
\text { chip }\end{array}$ & \\
\hline 39 & tertiary flake & no platform \\
\hline $\begin{array}{l}40 \\
41\end{array}$ & tertiary flake & no platform \\
\hline $\begin{array}{l}41 \\
42\end{array}$ & $\begin{array}{l}\text { core tragment } \\
\text { secondary flake }\end{array}$ & \\
\hline 43 & $\begin{array}{l}\text { secondary trake } \\
\text { core }\end{array}$ & single faceted plattorm, lipped \\
\hline $\begin{array}{l}44 \\
45\end{array}$ & $\begin{array}{l}\text { primary flake } \\
3 \text { chips }\end{array}$ & no platform \\
\hline & secondary flake & single faceted platform \\
\hline 46 & $\begin{array}{l}\text { tertiary flake } \\
\text { chunk } \\
2 \text { chips }\end{array}$ & single faceted platform \\
\hline 47 & primary flake & no platform \\
\hline $\begin{array}{l}48 \\
49\end{array}$ & $\begin{array}{l}\text { primary flake } \\
\text { chunk }\end{array}$ & single faceted platform \\
\hline 50 & secondary flake & no platform \\
\hline 51 & tertiary flake & single faceted platform \\
\hline 52 & tertiary flake & no platform \\
\hline 53 & tertiary flake & no platform \\
\hline 54 & secondary flake & $\begin{array}{l}\text { single faceted platform, ventral end } \\
\text { trimming/utilization }\end{array}$ \\
\hline 55 & chunk & \\
\hline 56 & secondary flake & $\begin{array}{l}\text { multi-faceted platform, dorsal, ventral, } \\
\text { trimming/utilization }\end{array}$ \\
\hline 57 & tertiary flake & no platform \\
\hline 58 & secondary flake & $\begin{array}{l}\text { no platform, ventral side, end trimming/ } \\
\text { utilization }\end{array}$ \\
\hline $\begin{array}{l}59 \\
60\end{array}$ & $\begin{array}{l}\text { chip } \\
2 \text { chunks }\end{array}$ & \\
\hline $\begin{array}{l}61 \\
62\end{array}$ & $\begin{array}{l}\text { tertiary flake } \\
\text { chip }\end{array}$ & single faceted platform \\
\hline 63 & 2 tertiary flakes & no platforms \\
\hline 64 & primary flake & no platform \\
\hline 65 & secondary flake & no platform, ventral end trimming \\
\hline
\end{tabular}


TABLE 4. (continued)

\begin{tabular}{cll}
$\begin{array}{c}\text { Artifact } \\
\text { No. }\end{array}$ & & Description \\
\cline { 1 - 1 } 66 & & secondary flake \\
& & chip \\
67 & & tertiary flake \\
68 & & uniface fragment \\
69 & & burned rock \\
70 & & burned rock \\
71 & & tertiary flake \\
72 & & tertiary flake \\
73 & & secondary flake \\
74 & & secondary flake \\
& & \\
75 & & secondary flake \\
& & 4 chunks \\
76 & & secondary flake \\
77 & & secondary flake \\
78 & & primary flake \\
79 & & secondary flake \\
80 & & secondary flake \\
81 & & core fragment \\
82 & & core fragment \\
83 & & secondary flake \\
84 & & tertiary flake \\
85 & & core fragment \\
86 & & primary flake \\
87 & & secondary flake \\
88 & & core fragment \\
89 & & tertiary flake \\
90 & & secondary flake \\
91 & & secondary flake \\
92 & & core \\
93 & & secondary flake \\
94 & & 2 core fragments \\
95 & & tertiary flake \\
96 & & primary flake \\
& chip \\
97 & & biface fragment \\
98 & & primary flake \\
99 & & tertiary flake \\
& &
\end{tabular}

Comments

no platform, ventral end trimming

ventral side trimming/utilization

dorsal notching

no platform

single faceted platform, lipped

no platform

single faceted platform, ventral side trimming/utilization

single faceted platform

single faceted platform

no platform

no platform

no platform

no platform

single faceted platform

no platform

no platform

no platform

no platform

no platform

no platform

no platform

single faceted platform

no platform

medial

no platform

single faceted platform, ventral side trimming/utilization 


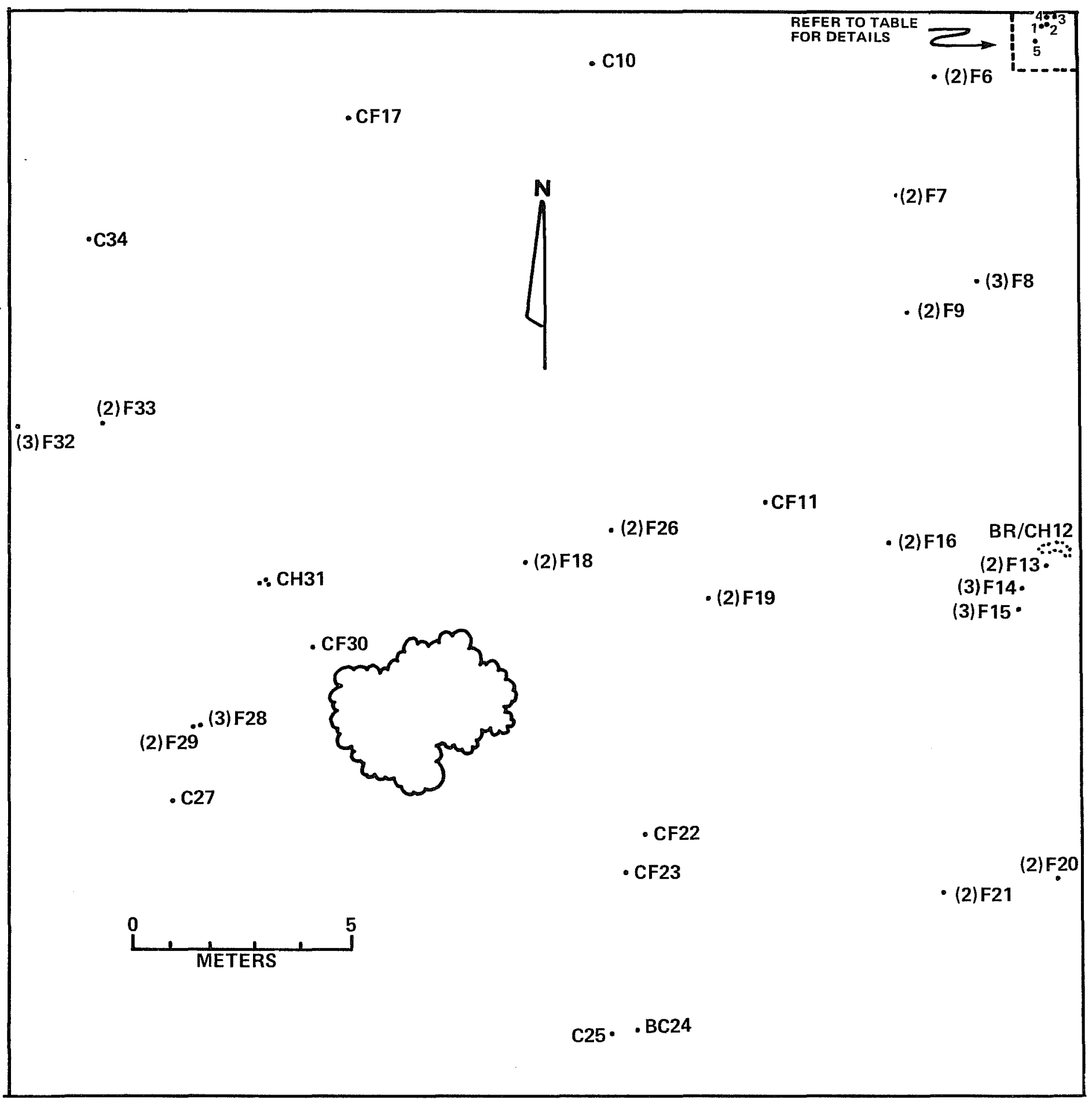

Figure 12. Map of $25 \mathrm{~m}^{2}$, No. 50. Distribution of cultural materials in random probability sample. Refer to page 16 and Table 5 for explanation of artifact descriptions. 
TABLE 5. 41 BX 68; ARTIFACT DESCRIPTION IN COLLECTION SQUARE 50

\begin{tabular}{|c|c|c|}
\hline $\begin{array}{l}\text { Artifact } \\
\text { No. } \\
\end{array}$ & Description & Comments \\
\hline 1 & primary flake. & single faceted platform \\
\hline 2 & secondary flake & no platform, dorsal end trimming/utilization \\
\hline $\begin{array}{l}3 \\
4\end{array}$ & $\begin{array}{l}\text { tertiary flake } \\
3 \text { chunks }\end{array}$ & single faceted platform, irregular blade flake \\
\hline 5 & chunk & \\
\hline 6 & secondary flake & single faceted platform, dorsal side trimming/ \\
\hline 7 & secondary flake & single faceted platform \\
\hline 8 & tertiary flake & $\begin{array}{l}\text { single faceted platform, ventral side trimming/ } \\
\text { utilization }\end{array}$ \\
\hline 9 & secondary flake & no platform \\
\hline 10 & core & \\
\hline $\begin{array}{l}11 \\
12\end{array}$ & $\begin{array}{l}\text { core fragment } \\
4 \text { burned rocks }\end{array}$ & \\
\hline 13 & secondary flake & no platform \\
\hline $\begin{array}{l}14 \\
15\end{array}$ & $\begin{array}{l}\text { tertiary flake } \\
\text { tertiary flake }\end{array}$ & $\begin{array}{l}\text { no platform, irregular distal blade fragment } \\
\text { single faceted platform, dorsal trimming/ }\end{array}$ \\
\hline 16 & secondary flake & $\begin{array}{l}\text { utilization, all edges } \\
\text { single faceted platform, dorsal/ventral } \\
\text { trimming/utilization, ail edges }\end{array}$ \\
\hline 17 & core fragment & \\
\hline 18 & secondary flake & no platform \\
\hline 19 & secondary flake & no platform \\
\hline 20 & secondary flake & $\begin{array}{l}\text { multi-faceted platform, ventral trimming/ } \\
\text { utilization, all edges }\end{array}$ \\
\hline 21 & secondary flake & no platform, ventral side trimming/utilization \\
\hline 22 & secondary flake & no platform \\
\hline 23 & core fragment & \\
\hline $\begin{array}{l}24 \\
25\end{array}$ & $\begin{array}{l}\text { battered cobble } \\
\text { core }\end{array}$ & \\
\hline 26 & secondary flake & single faceted platform \\
\hline 28 & tertiary flake & no platform \\
\hline 29 & secondary flake & no platform \\
\hline $\begin{array}{l}30 \\
31\end{array}$ & $\begin{array}{l}\text { core fragment } \\
3 \text { chunks }\end{array}$ & \\
\hline 32 & tertiary flake & single faceted platform \\
\hline 33 & secondary flake & no platform \\
\hline 34 & core & \\
\hline
\end{tabular}




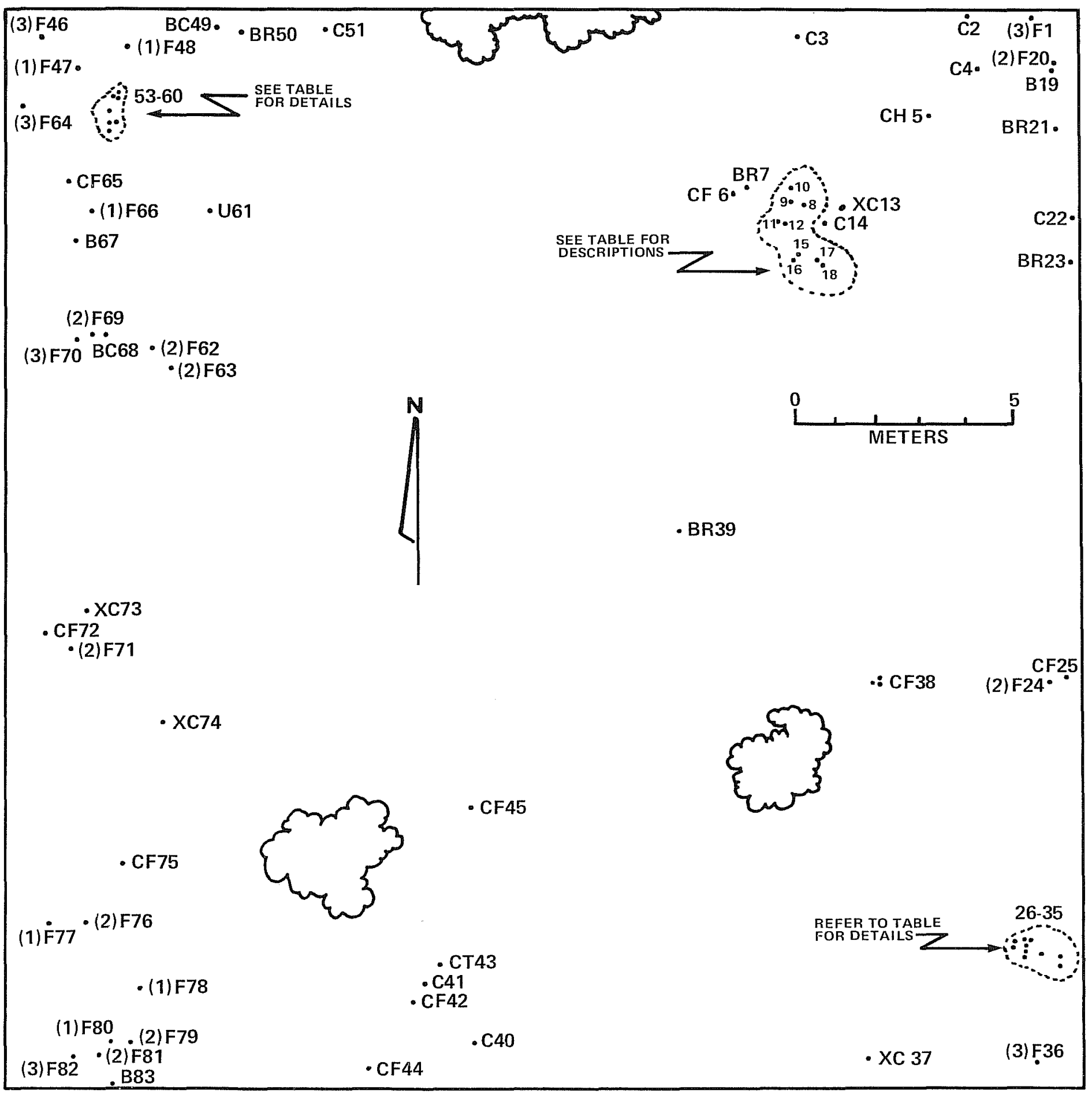

Figure 13. Map of $25 \mathrm{~m}^{2}$, No. 59. Distribution of cultural materials in random probability sample. Refer to page 16 and Table 6 for explanation of artifact designations. 
TABLE 6. 41 BX 68; ARTIFACT DESCRIPTION IN COLLECTION SQUARE 59

Artifact

No.

1

2
Description

tertiary flake

core

sma'll core

core

chunk

core fragment

burned limestone rock core fragment

burned limes tone rock burned limestone rock core fragment burned limes tone rock expended core core core fragment burned limestone rock expended core core fragment biface secondary flake burned limestone rock core fragment burned limestone rock secondary flake

core fragment tertiary flake

\section{3 chips}

secondary flake secondary flake 5 chips tertiary flake secondary flake secondary flake

tertiary flake 2 secondary flakes tertiary flake expended core 3 core fragments burned rock core core core fragment core tool core fragment
Conments

no platform; ventral trimming/utilization along sides and end battering, edge trimming/utilization noted heavily battered marginally trimmed, no edge wear noted no platform

battered

single faceted platform, ventral side and edge trimming/utilization battered single faceted platform, proximal end shows ventral trimming/utilization

no platform

no platform

no platform

no platform

no platform, dorsal trimming/utilization noted

no platform

no platform

no platform

battering noted

extensive end retouch 
TABLE 6. (continued)

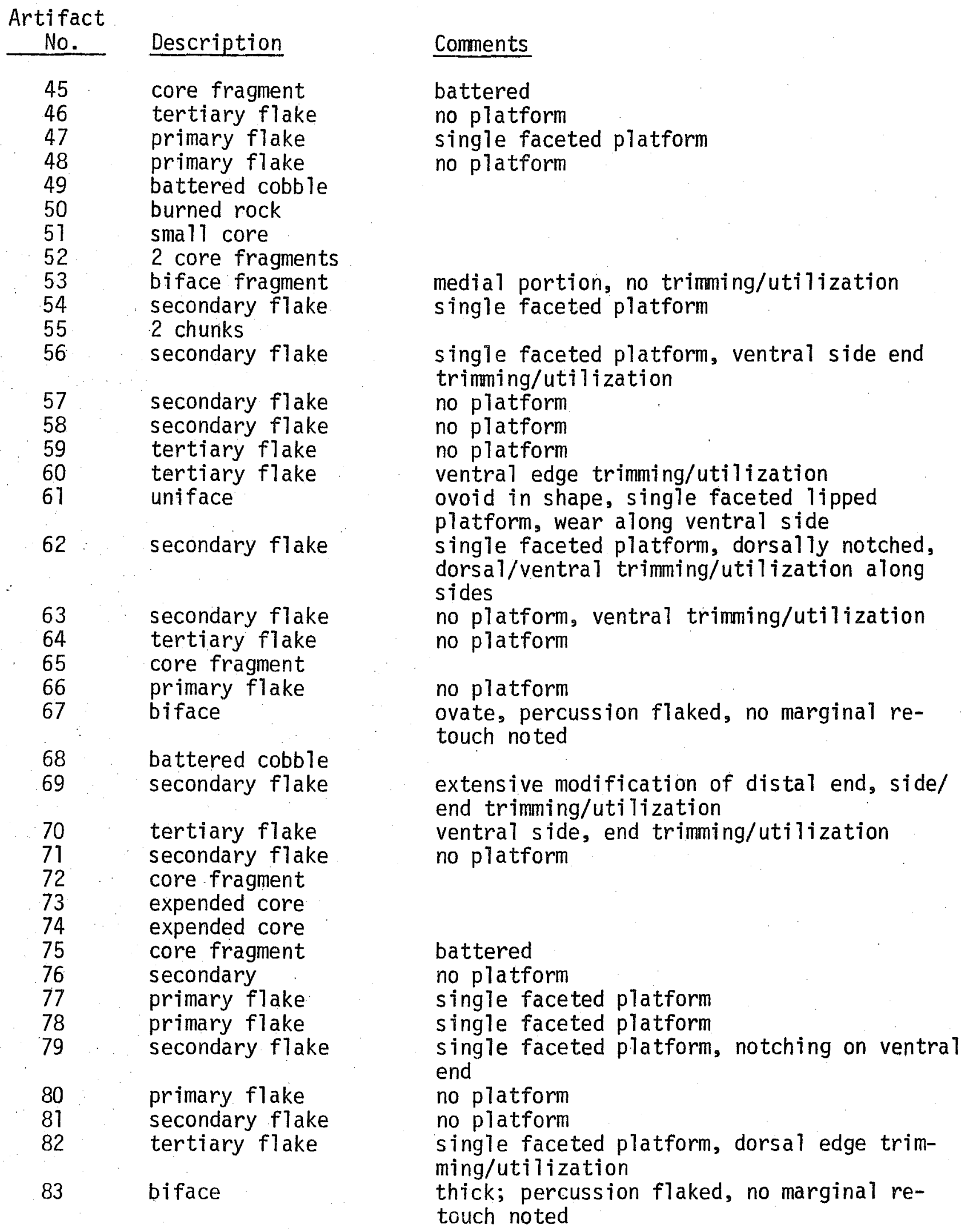




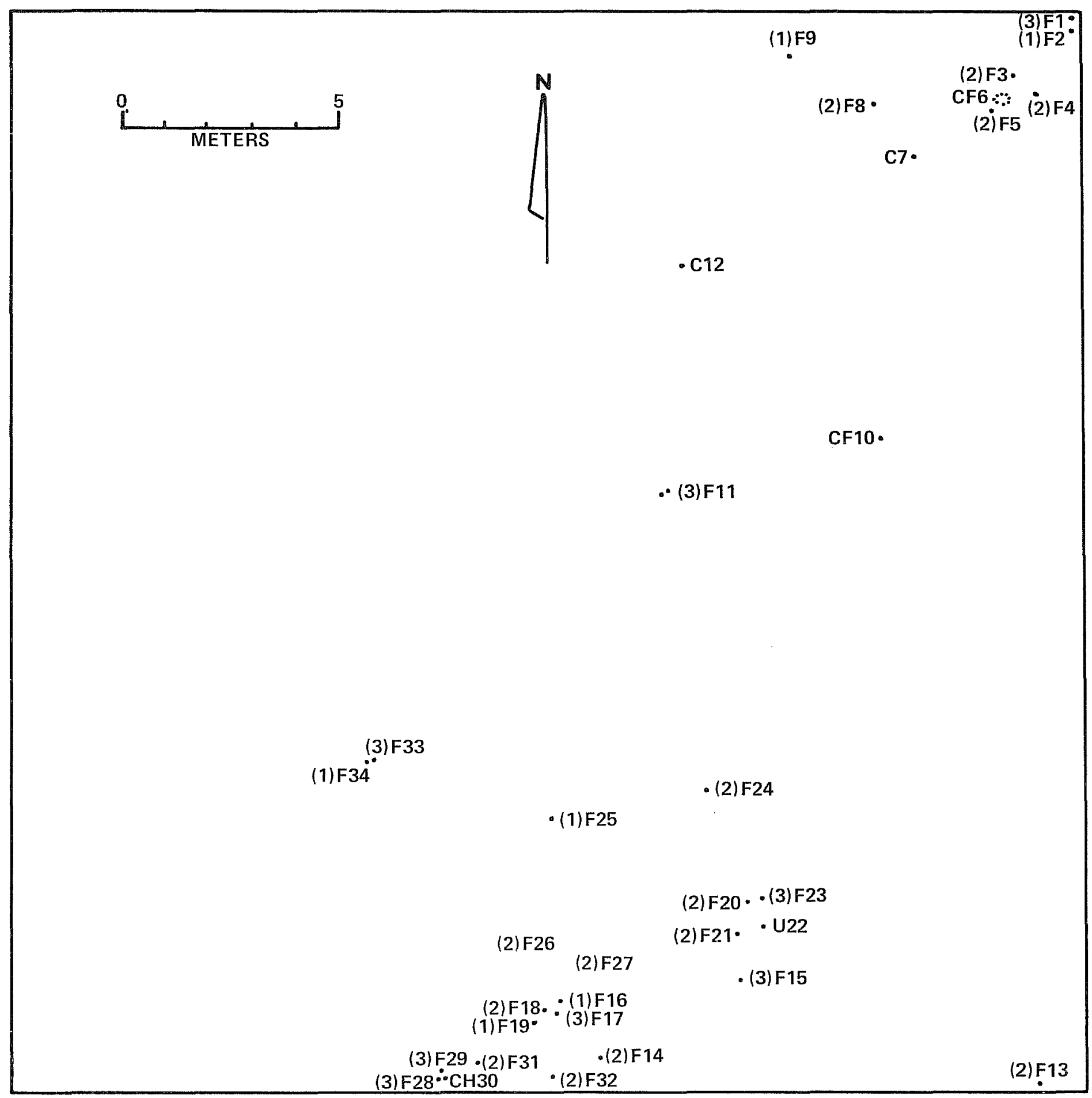

Figure 14. Map of Control Square C-1. Distribution of cultural materials in random probability sample. Refer to page 16 and Table 7 for explanation of artifact designations. 
TABLE 7. 41 BX 68; ARTIFACT DESCRIPTION IN COLLECTION SQUARE C-1

Artifact

No.

$$
\begin{aligned}
& 1 \\
& 2 \\
& 3 \\
& 4 \\
& 5 \\
& 6 \\
& 7 \\
& 8
\end{aligned}
$$

Description

tertiary flake primary flake secondary flake secondary flake secondary flake 3 core fragments core secondary flake secondary flake core fragment 2 tertiary flakes core secondary flake

secondary flake tertiary flake 2 primary flakes tertiary flake

secondary flake primary flake secondary flake

secondary flake

uniface

tertiary flake secondary flake primary flake secondary flake

secondary flake tertiary flake tertiary flake chunk secondary flake secondary flake tertiary flake primary flake
Comments

no platform

no platform

no platform, dorsal end trimming/utilization single faceted platform single faceted platform

multi-faceted platform, dorsal, ventral trimming/utilization no platform

single faceted platforms

single faceted platform, dorsal side trimming/utilization

dorsal side trimming/utilization

no platform, dorsal trimming/utilization

no platforms

no platform, patinated, dorsal end trimming/ utilization

no platform

no platform, dorsal side trimming/utilization single faceted platform, dorsal trimming/ utilization all edges

single faceted platform, dorsal, ventral trimming/utilization

rectangular in shape, no platform, extensive retouch on ventral surfaces

single faceted platform, dorsal side trimming/utilization

no platform

no platform

single faceted platform, dorsal side trimming/utilization

no platform

no platform

single faceted platform

no platform

multi-faceted platform, dorsal side trimming/utilization

no platform, dorsal side, end trimming/ utilization no platform 


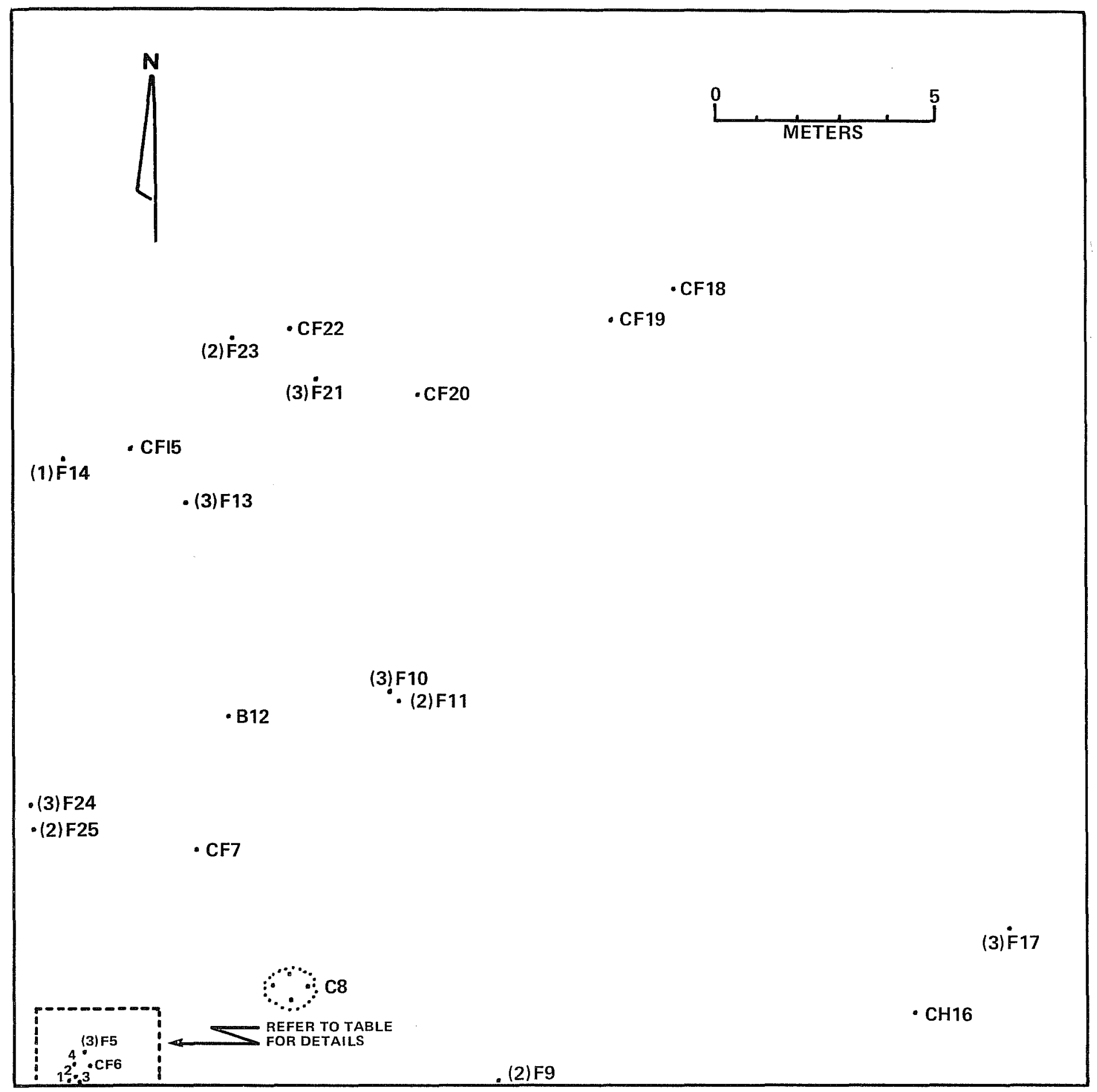

Figure 15. Map of Control Square C-2. Distribution of cultural materials: in random probability sample. Refer to page 16 and Table 8 for explanation of artifact designations. 
TABLE 8. 41 BX 68; ARTIFACT DESCRIPTION IN COLLECTION SQUARE C-2

\begin{tabular}{cll}
$\begin{array}{cl}\text { Artifact } \\
\text { No. }\end{array}$ & & Description \\
\cline { 1 - 1 } 1 & & secondary flake \\
2 & & chunk \\
3 & & secondary flake \\
4 & & tertiary flake \\
5 & & tertiary flake \\
6 & & core fragment \\
7 & & core fragment \\
8 & & 4 cores \\
9 & & secondary flake \\
& & \\
10 & & tertiary flake \\
11 & & secondary flake \\
12 & & biface \\
13 & & tertiary flake \\
14 & & primary flake \\
15 & & core fragment \\
16 & chunk \\
17 & tertiary flake \\
18 & & core fragment \\
19 & core fragment \\
20 & core fragment \\
21 & tertiary flake \\
22 & core fragment \\
23 & & secondary flake \\
24 & & sertiary flake \\
25 & & secondary flake \\
& &
\end{tabular}

Comments

single faceted platform, dorsal trimming/ utilization

no platform

no platform

no platform

scattered in a $1 \mathrm{~m}$ diameter

single faceted platform, lipped, dorsal

side trimming/utilization

single faceted platform, ventral side trimming/utilization

no platform, dorsal/ventral trimming/utilization crude, no marginal retouch

single faceted platform

no platform

ventral triming/utilization

single faceted platform, ventral side, end trimming/utilization

single faceted platform

no platform

multi-faceted platform

multi-faceted platform 
HISTOGRAMS SHOWING COMPARISON OF SELECTED LITHIC MATERIALS* IN $25 \mathrm{~m}^{2}$ COLLËCTION SQUARES.
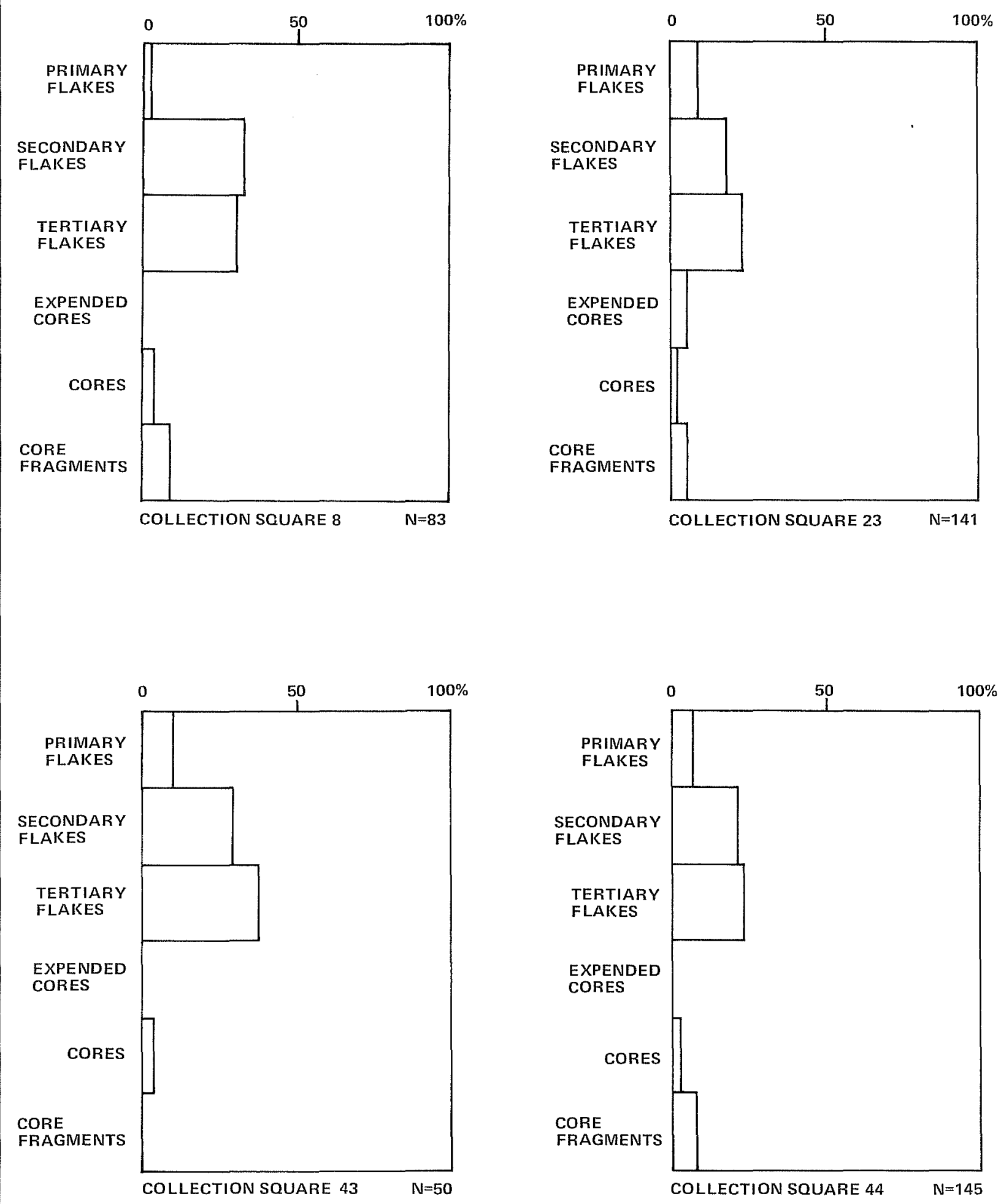

* based on ratio between selected debris and total lithic materials in souare.

Figure 16. Histograms Showing Comparisons of Selected Lithic Materials. 
SUMMARY AND CONCLUSIONS

The analysis of $41 \mathrm{BX} 68$ suggests an extensive prehistoric quarry-workshop area with an intense concentration of lithic debris on or near the higher elevations of the site. Limited subsurface testing and random probability sampling/mapping operations reflect a broad spectrum of quarry-workshop lithic reduction processes seemingly indiscriminately mixed throughout the site. Subsurface testing and observation of eroded materials throughout different areas of the site indicate an extensive and intense layer of lithic debris between 8 to $11 \mathrm{~cm}$. The vicinity of TP-1, the only area with any soil depth, appears to have been a most intense activity locality. The significance of this locality is not yet fully understood although it may be that: (1) this area may have actually been a separate concentration, distinct from the larger concentration by distance and frequency of artifacts or (2) it may have existed as the most concentrated activity area within the larger concentration defined earlier. If the latter assumption were true, it cannot be established whether the vicinity of TP-1 was a possible occupation locality within the boundaries of the site. The high ratio of cores and core fragments implies the primary concern was lithic reduction, al though $\mathrm{TP}-\mathrm{T}$ 's proximity to Elm Creek may reflect other aboriginal interests.

While this report has formed a brief description of 41 BX 68 and identified elements of material frequency and distributions, it should be noted these observations are only an assessment of sampled materials from an archaeological site that has been known to relic collectors for years. Any judgments made are somewhat compromised by lack of evidence, deficiencies of a newly formulated methodology or the lack of information, generally, on south central Texas quarry-workshop areas.

\section{RECOMMENDATIONS}

41 BX 68 represents an unusual1y extensive quarry-workshop area in northern Bexar County. Because of the lack of diagnostic artifacts, the absence of other major cultural features and the fact that the densest concentration of lithic materials is located on higher elevations presumably above a flood pool of the floodwater retarding structure, no further work is recommended at this site. It is recommended, however, that if surface alteration in the form of borrow pits or landmoving takes place in the vicinity of TP-7, an archaeologist should be present to identify previously unrecorded or unidentified buried features. 


\section{REFERENCES CITED}

Assad, C.

1978 An Evaluation of Archaeological Sites in the Vicinity of Floodwater Retarding Structure No. 2, Dry Comal Creek, Comal County, Texas. Center for Archaeological Research. The University of Texas at San Antonio, Archaeological Survey Report 50.

Blair, W. F.

1950 The Biotic Provinces of Texas. Texas Journal of Science 2(1):93-116.

Brown, D., P. Lukowski, T. R. Hester and J. Eaton

1977 Archaeological Assessment of Two Sites in the Vicinity of Floodwater Retarding Structure No. 11, Salado Creek Watershed, Bexar County, Texas. Center for Archaeological Research. The University of

Texas at San Antonio, Archaeological Survey Report 35.

Crabtree, D. E.

1972 An Introduction to Flintworking. Occasional Papers of the Idaho State University Museum 28, Pocatel10.

Davis, W. B.

1974 The Mammals of Texas. Texas Parks and Wildlife Department, Bulletin 41.

Fawcett, W. B., Jr.

1972 The Prehistory of Bexar County: A Study of Previous Work in South Central Texas. Bulletin, Lower Plains Archaeological Society 2 (for 1971).

1974 Preliminary Analysis of Prehistoric Utilization of Upland Areas Adjacent to Leon Creek, South Central Texas. La Tierra 1(1):27-31.

Fox, A. A.

1977 An Archaeological Assessment of the San Antonio 201 Wastewater Treatment Project. Center for Archaeological Research. The University of Texas at San Antonio, Archaeological Survey Report 41.

Gerstle, A., T. C. Kelly and C. Assad

1978 The Fort Sam Houston Project: An Archaeological and Historical Assessment. Center for Archaeological Research, The University of Texas at San Antonio, Archaeological Survey Report 40. 
Gould, R. A.

1969 Yiwara: Foragers of the Australian Desert. New York: Scribner and Sons.

Gunn, J. and R. Mahula

1977 Culture and Climatic Change in Central Texas. Center for Archaeological Research. The University of Texas at San Antonio, Special Report 5.

Gunn, J., R. Mahula and J. B. Sollberger

1976 The Sollberger Distribution. La Tierra 3(4):2-8.

Hamilton, W. R., A. R. Woolley and A. C. Bishop

1974 A Guide to Minerals, Rocks, and Fossils. New York: Crescent Books.

Heizer, R. F. and A. E. Treganza

1972 Mines and Quarries of the Indians of California. Ballena Press, Ramones, California.

Hester, T. R.

1968 Folsom Points from Southwest Texas. Plains Anthropologist 13(40):117.

1974 Fluted Points and South Texas Archaeology. Texas Archaeology $18(2): 11-14$.

1975 A Chronological Overview of Prehistoric Southern and South-Central Texas. Paper presented at the conference "The Prehistory of Northeastern Mexico and Texas" Monterrey, Mexico, April 23-26, 1975.

1976 The Archaic of Southern Texas. In: The Texas Archaic: A Symposium. T. R. Hester, Editor. Center for Archaeological Research, The University of Texas at San Antonio, Special Report 2:83-90.

1977 The Current Status of Paleo-Indian Studies in Southern Texas and Northeastern Mexico. In: "Paleoindian Lifeways." E. Johnson, Editor. The Museum Journal XVII, West Texas Museum Association, Texas Tech University, Lubbock, Texas.

Hester, T. R. and R. F. Heizer

1973 Bibliography of Archaeology I: Experiments, Lithic Technology and Petrography. Addison-Wesley Modules in Anthropology 29. 
Hester, T. R. and T. C. Hill, Jr.

1975 Some Aspects of Late Prehistoric and Protohistoric Archaeology in Southern Texas. Center for Archaeological Research. The University of Texas at San Antonio, Special Report 1.

Hester, T. R., F. A. Bass, Ir., A. A. Fox, T. C. Kelly, M. F. Chadderdon and E. S. Harris

1974 Archaeological Survey of Areas Proposed for Modification in the Salado Creek Watershed, Bexar County, Texas. Center for Archaeological Research. The University of Texas at San Antonio, Archaeological Survey Report 3.

Holmes, W. H.

1894 An Ancient Quarry in Indian Territory. Bureau of Ethnology, Smithsonian Institute, Washington, D.C.

Hudson, W. R., Jr., W. M. Lynn and D. Scurlock

1974 Walker Ranch, An Archaeological Reconnaissance and Excavations in Northern Bexar County, Texas. Texas Historical Commission, Report 26.

Jaquier, J. A., W. Cox, T. R. Hester, F. Valdez, Jr. and A. J. McGraw

1978 Archaeological Test Excavations at Site 41 BX 228, Walker Ranch, Bexar County, Texas. Center for Archaeological Research. The university of Texas at San Antonio, Archaeological Survey Report 46.

Katz, P.

197841 BX 300 Mitigation. Report in preparation.

Kelly, T. C. and T. R. Hester

1975a Additional Archaeological Survey in the Dry Comal Watershed, Comal County, South Central Texas. Center for Archaeological Research, The University of Texas at San Antonio, Archaeological Survey Report 10.

1975b Archaeological Investigations at Four Sites in the Dry Coma 7 Watershed, Comal County, South Central Texas. Center for Archaeological Research. The University of Texas at San Antonio, Archaeological Survey Report 15.

McGraw, A. J.

1977 A Preliminary Archaeological Survey Along the Medio Creek Drainage, Southwestern Bexar County, Texas. Center for Archaeological Research. The University of Texas at San Antonio, Regional Studies 3. 
McGraw, A. J. and F. Valdez, Jr.

1977a An Archaeological Assessment of the Tobins Oakwell Farm, Northern Bexar County. Center for Archaeological Research. The University of Texas at San Antonio, Archaeological Survey Report 43.

1977b Testing and Limited Excavation at Rockshelter and Terrace Sites Along the Salado Creek Drainage, Northern Bexar County. Center for Archaeological Research. The University of Texas at San Antonio, Archaeological Survey Report 55.

McGraw, A. J., F. Valdez, Jr. and W. Cox

1977 An Archaeological Survey of Areas Proposed for Modification in the Encino Park Development, Northern Bexar County. Center for Archaeological Research. The University of Texas at San Antonio, Archaeological Survey Report 39.

Newcomb, W. W., Jr.

1961 The Indians of Texas. University of Texas Press, Austin. Patterson, L. W.

1975 A Quarry Site in Medina County, Texas. La Tierra 2(1):19-23. Redman, C. L.

1974 Archaeological Sampling Strategies. Addison-Wesley Module in Anthropology 55.

Reher, C. A.

1977 Settlement and Subsistence Along the Lower Chaco River. University of New Mexico Press, Albuquerque.

Scurlock, D. and W. R. Hudson

1973 An Archaeological Investigation of Walker Ranch. Texas Historical Commission, Austin.

Smith, H. P., Jr. and K. McDonald

1975 An Archaeological Survey of Friedrich Park, Bexar County, Texas. Center for Archaeological Research. The University of Texas at San Antonio, Archaeological Survey Report 12.

Sollberger, J. B. and T. R. Hester

1972 The Strohacker Site: A Review of Pre-Archaic Manifestations in Texas. Plains Anthropologist 17(58):326-344. 
Taylor, F. B., R. B. Haily and B. L. Richmond

1966 Soil Survey of Bexar County, Texas. U.S. Department of Agriculture Soil Conservation Service, Series 1962:12.

Wilmsen, E.

1970 Lithic Analysis and Cultural Inference: A Paleo-Indian Case. Anthropological Papers of the University of Arizona 16. University of Arizona Press, Tucson. 